\title{
Advances in enzyme bioelectrochemistry
}

\author{
ANDRESSA R. PEREIRA ${ }^{1}$, GRAZIELA C. SEDENHO ${ }^{1}$, JOÃO C. P. DE SOUZA ${ }^{1,2}$ and FRANK N. CRESPILHO ${ }^{1}$ \\ ${ }^{1}$ São Carlos Institute of Chemistry, University of São Paulo, Av. Trabalhador São-carlense, 400, 13560-970 São Carlos, SP, Brazil \\ ${ }^{2}$ Goiano Federal Institute, Rodovia Sul Goiana, Km 1, 75901-970 Rio Verde, GO, Brazil
}

Manuscript received on July 5, 2017; accepted for publication on October 11, 2017

\begin{abstract}
Bioelectrochemistry can be defined as a branch of Chemical Science concerned with electron-proton transfer and transport involving biomolecules, as well as electrode reactions of redox enzymes. The bioelectrochemical reactions and system have direct impact in biotechnological development, in medical devices designing, in the behavior of DNA-protein complexes, in green-energy and bioenergy concepts, and make it possible an understanding of metabolism of all living organisms (e.g. humans) where biomolecules are integral to health and proper functioning. In the last years, many researchers have dedicated itself to study different redox enzymes by using electrochemistry, aiming to understand their mechanisms and to develop promising bioanodes and biocathodes for biofuel cells as well as to develop biosensors and implantable bioelectronics devices. Inside this scope, this review try to introduce and contemplate some relevant topics for enzyme bioelectrochemistry, such as the immobilization of the enzymes at electrode surfaces, the electron transfer, the bioelectrocatalysis, and new techniques conjugated with electrochemistry vising understand the kinetics and thermodynamics of redox proteins. Furthermore, examples of recent approaches in designing biosensors and biofuel developed are presented.
\end{abstract}

Key words: bioelectrocatalysis, biofuel cells, bioelectrochemistry, immobilization, protein-electrode interactions, redox enzymes.

\section{INTRODUCTION}

The term "bioelectrochemistry" can be defined as the area of the science that utilizes electrochemical principles and techniques to investigate processes of biological relevance (Guidelli et al. 2001), in particular, focusing on the electrochemical properties of biological molecules. Since 1933, when Brdicka (Brdicka 1933) discovered the

Correspondence to: Frank Nelson Crespilho

E-mail: frankcrespilho@iqsc.usp.br

* Contribution to the centenary of the Brazilian Academy of Sciences. catalytic properties of proteins, scientists have studied their bioelectrochemistry, and the investigation of the fundamental features of electron transfer (ET) in proteins has aroused great interest for the development of devices such as biosensors and biofuel cell for medical applications.

Although there are many different kinds of proteins, research into the electrochemistry of redox enzymes increased in the late 1960s, mainly because of the promise of viable biosensors for medical applications such as blood glucose determination (Czaban 1985). Initially, enzyme 
electrochemistry was performed in solution, but good results were not obtained because of the adsorption and denaturation of the enzymes on the electrode surfaces and the highly irreversible electrode reactions that are related to electrode fouling (Armstrong 1990). At the same time, electrochemical enzyme biosensors were developed using enzymes immobilized in films on electrodes (Kauffmann and Guilbault 1992, Guilbault 1984), and it was demonstrated that enzymes immobilized in films retain high catalytic activity, even though mediators must be used to shuttle electrons between the enzymes and the electrode surfaces instead of direct electron transfer (DET). Although bioelectrochemistry and bioelectrocatalysis have been investigated since 1933, Table I summarizes the books that were published in this field for the last 20 years. Besides proteins, DNA is another biomolecule that has been studied recently by electrochemistry (Bartels et al. 2017); however, this topic is out of the scope of this review.

Here, we will summarize some important topics in the field of bioelectrochemistry related to enzymes, such as the enzymes that have been studied to develop different types of biosensors and the bioanodes and biocathodes developed for biofuel cells. In addition, we will discuss how ET occurs between enzymes and the electrode surfaces. Moreover, we will discuss how modification of the protein-electrode interface could improve the ET because this a key parameter for improving the communication between the protein and the electrode surface. Lastly, some examples of the applications of this area are given, such as the development of biosensors and biofuel cells.

\section{REDOX ENZYMES}

Enzymes are divided into six main classes: oxidoreductases, transferases, hydrolases, lyases, isomerases, and ligases, and this division is based on the type of reaction catalyzed by the enzyme (Nelson and Cox 2005). Here, we are interested in the oxidoreductases, which are responsible to catalyze biological oxidation and reduction reactions. The oxidoreductases can be divided into dehydrogenases, oxygenases, and oxidases (May and Padgette 1983), where the dehydrogenases are

TABLE I

Books published in the field of bioelectrochemistry in the last 20 years.

\begin{tabular}{|c|c|c|}
\hline Title & Year & Reference \\
\hline Encyclopedia of electrochemistry: bioelectrochemistry: volume 9 & 2002 & Bard et al. 2002 \\
\hline Bioelectrochemistry of membranes & 2004 & Walz et al. 2004 \\
\hline Bioinorganic electrochemistry & 2007 & Hammerich and Ulstrup 2007 \\
\hline Bioelectrochemistry research developments & 2008 & Bernstein 2008 \\
\hline Bioelectrochemistry: fundamentals, experimental techniques and applications & 2008 & Bartlett 2008 \\
\hline $\begin{array}{l}\text { Bioelectrochemical systems: from extracellular electron transfer to biotechnological } \\
\text { application }\end{array}$ & 2009 & Rabaey et al. 2009 \\
\hline Bioelectrochemistry: fundamentals, applications and recent developments & 2011 & Alkire et al. 2011 \\
\hline Biological electrochemistry & 2012 & Dryhurst 2012 \\
\hline Nanobioelectrochemistry: from implantable biosensors to green power generation & 2013 & Crespilho 2013 \\
\hline Implantable bioelectronics: devices, materials and applications & 2014 & Katz 2014 \\
\hline Biofilms in bioelectrochemical systems: from laboratory practice to data interpretation & 2015 & Beyenal and Babauta 2015 \\
\hline Electrochemical biosensors & 2015 & Cosnier 2015 \\
\hline Bioelectrochemistry of biomembranes and biomimetic membranes & 2016 & Guidelli 2016 \\
\hline Biophotoelectrochemistry: from bioelectrochemistry to biophotovoltaics & 2017 & Jeuken 2016 \\
\hline
\end{tabular}


considered the largest type of this class of enzyme. Dehydrogenases can be sub-divided by their cofactor and coenzymes requirements, for example, nicotinamide adenine dinucleotide phosphate (NAD(P))-dependent or flavin coenzymedependent, and they are used in the development of bioanodes of biofuel cells. For example, glucose dehydrogenase (GDh) and alcohol dehydrogenase (ADH) are two enzymes that have been utilized to develop biodevices. GDh catalyzes the oxidation of glucose to gluconolactone, according to Equation 1 and $\mathrm{ADH}$ catalyzes the reversible interconversion of alcohols to aldehydes or ketones, where Equation 2 is an example of ethanol oxidation utilizing an ADH $\beta$-nicotinamide adenine dinucleotide $\left(\mathrm{NAD}^{+}\right)$-dependent enzyme.

glucose $+\mathrm{GDh}(\mathrm{FAD}) \rightarrow$ gluconolactone $+\mathrm{GDh}\left(\mathrm{FADH}_{2}\right)(1)$

$$
\mathrm{CH}_{3} \mathrm{CH}_{2} \mathrm{OH}+\mathrm{NAD}^{+} \rightleftharpoons \mathrm{CH}_{3} \mathrm{CHO}+\mathrm{NADH}+\mathrm{H}^{+}
$$

Oxygenases are known to incorporate molecular oxygen directly into organic substrates and exhibit very high efficiency and selectivity. They convert alkanes to alcohols, olefins to epoxides, sulfides to sulfoxides, and cleave aromatic rings or oxidize their substituents. The oxygenases are divided into two classes: dioxygenases and monooxygenases. The first type incorporates both atoms of an oxygen molecule into the organic substrate, while the second incorporates only one atom of molecular oxygen into the substrate, and the other oxygen atom is reduced to water at the expense of a reductant, such as NAD(P)H (May and Padgette 1983).

The last type of oxidoreductases is the oxidases, which include flavoprotein oxidases, metalloflavoprotein oxidases, and hemeprotein oxidases. In this case, the most used enzyme for electrochemical studies is glucose oxidase (GOx). This enzyme is responsible for the catalytic oxidation of the glucose to gluconolactone using molecular oxygen as an electron acceptor, and its product is non-enzymatically hydrolyzed to gluconic acid and hydrogen peroxide (Bankar et al. 2009).

All enzymes have a polypeptide backbone arranged in secondary and tertiary structures and feature a redox cofactor that might be metal complexes or an organic molecule bound to a specific site. Thus, the most common redox cofactors, so-called redox-active centers, are quinones, flavins, NAD(P)H, hemes, iron-sulfur clusters, and copper centers. The quinones are twoelectron, two-proton redox centers and are known to be hydrogen atom carriers, which implies that their redox reactions vary with $\mathrm{pH}$. For this species, the intermediate semiquinone radical is accessible and often stable, allowing sequential one-electron oxidation or reduction reactions (Bartlett 2008). Flavins are divided into flavin adenine dinucleotide (FAD), and flavin mononucleotide (FMN), and they are also two-electron, two-proton redox centers (Walsh 1980). As for quinones, their redox potentials are $\mathrm{pH}$-dependent.

$\mathrm{NAD}^{+}$and $\mathrm{NADP}^{+}$are two-electron, oneproton redox couples. In this case, the intermediate radicals are not accessible, and they are considered hydride carriers in biological systems. The difference between them is the presence of an additional phosphate on the ribose ring of the adenosine; however, their redox potentials are the same (Bartlett 2008).

Heme groups are formed by a porphyrin ring, comprising four pyrrole rings linked by methylene bridges with a $\mathrm{Fe}^{2+}$ ion coordinated in the center. There are different heme types, which vary according to the substitution around the porphyrin ring; consequently, the redox potential of the iron center is affected, causing the redox potentials of these groups to vary. For iron-sulfur clusters, iron atoms are bonded to sulfur atoms on cysteine residues of the associated protein and inorganic sulfur atoms, and these function as multielectron 
redox centers that can pick up or release one electron at a time (Beinert et al. 1997). Lastly, there are copper centers, where copper acts as a oneelectron center, changing between the $\mathrm{Cu}^{+}$and $\mathrm{Cu}^{2+}$ states.

\section{DIRECT ELECTRON TRANSFER AND MEDIATED ELECTRON TRANSFER IN PROTEINS}

An enzyme reaction at an electrode surface can proceed in two ways. The first approach is mediated electron transfer (Figure 1a), which is based on the utilization of redox mediators and, in this case, the enzyme catalyzes the oxidation or reduction of the mediator (Cardosi and Turner 1987, Bartlett et al. 1991). In this type of system, the catalytic process involves the enzymatic transformation of the analyte and the mediator. In the second, in contrast, direct (mediatorless) electron transfer occurs (Figure 1b) (Tarasevich 1985). In this case, the electron is directly transferred from the active center of the enzyme to the electrode surface, which provides important information about the thermodynamics and kinetics of the biological redox process.

Because many proteins have their redox sites buried deeply in their structure, the redox center is isolated from the environment; thus, DET with bulk electrodes is hindered. In this case, the electrical communication between the enzyme and the electrode surface can be established by using charge-carriers, so-called ET mediators. These agents are artificial electron acceptor or donor molecules able to shuttle electrons from the redox center of the enzyme to the electrode and vice versa (Katz et al. 2007).

An ideal redox mediator should provide a rapid reaction with the enzyme, exhibit reversible electrochemistry (large rate constant for the interfacial ET at the electrode surface), be stable in the oxidized and reduced forms under the working conditions, have a low overpotential for regeneration, and do not participate in side reactions during ET. Furthermore, the redox potential of the mediator should be more positive for oxidative biocatalysis and more negative for reductive biocatalysis, compared to the redox potential of the enzyme active site (Chaubey and Malhotra 2002).

There are several redox mediators ranging from organic to inorganic molecules, including methylene blue, methyl violet, Prussian blue, thionin, toluidine blue, quinone derivates, ferrocene and its derivates, and inorganic redox ions such as ferri/ferrocyanide (Kavanagh and Leech 2013). For the selection of a suitable mediator, some factors must be considered, such as the redox potential, stability, and solubility under the working conditions, and the properties of the enzyme and the mediator (Kavanagh and Leech 2013). This is because the hydrophobic/hydrophilic properties of the mediator and the enzyme and the size and shape of the mediator affect the penetration of the mediator close to the enzyme redox site (Katz et al. 2007).

Several designs of mediated bioelectrochemical systems have been developed. These systems can involve from soluble enzymes with diffusional electron mediators to sophisticated architectures with multistep mediated ET. The simplest system configuration involves the enzyme and mediator in solution, i.e., homogeneous mediation. In this case, the mediator reacts with the enzyme in the bulk solution and diffuses to the electrode, where it is regenerated (Kavanagh and Leech 2013). This kind of system is useful for studying the enzymemediator interactions, for example, the influence of structure mediators in the redox reaction with the enzyme (Forrow et al. 2002). Other systems employ heterogeneous electron mediation (Patolsky et al. 1998), where the enzyme (or mediator) is immobilized on the electrode surface or in a 3-D matrix, and the mediator (or enzyme) diffuses from the bulk solution. Alternatively, both enzyme and mediator can be incorporated into the electrode surface (Reuillard et al. 2013, Luz and Crespilho 
electrode

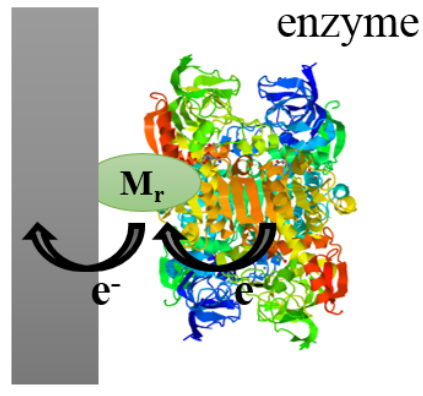

electrode

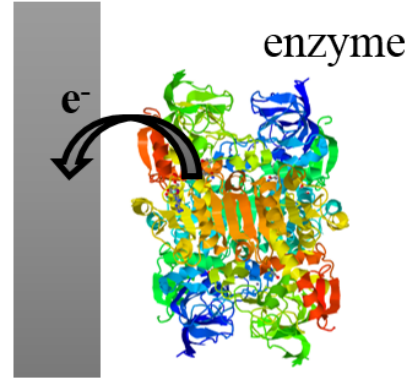

Figure 1 - Schematic representation of (a) mediated electron transfer, where $M_{r}$ corresponds to the redox mediator, and (b) direct electron transfer.

2016). These systems produce high currents because the enzyme and mediator are present in high concentration at the electrode surface. An alternative approach to the mediated system is the use of soluble enzymes functionalized with electron mediators. For example, GOx has been covalently modified with ferrocene, osmium, and ruthenium complexes by the formation of bonds with lysine or histidine residues (Katz et al. 2007).

The utilization of mediated ET system must be carefully considered. Although it facilitates the electrical connection between enzymes and electrodes, providing biofuel cells with large currents, power outputs, and small voltage losses, resulting in sensitive biosensors, the use of mediators can limit the application of bioelectrochemical devices. This is because many redox mediators are toxic, which precludes the implantation of these devices in vivo (Falk et al. 2013). Moreover, the miniaturization of devices with mediated ET processes is quite complicated because the compartmentalization of the device using membranes is necessary.

Nowadays, many researchers are interested in achieving DET between an electrode and the active center of an enzyme, and this is very important for the development of next-generation enzyme biosensors and biofuel cells (Willner 2002). In addition, non-mediated bioelectrochemistry at solid electrodes has been developed as a potentially powerful method for mechanistic studies of redox proteins (Frew and Hill 1988). DET has been observed in redox proteins where the redox center is close to the surface of the protein, such as cytochrome $c$ (Eddowes and Hill 1977) and ferredoxin (Armstrong et al. 1982). However, for proteins such as GOx where the prosthetic group, FAD, is deeply embedded within a protective protein shell, it is difficult to observe this type of charge transfer.

An immobilized enzyme capable of DET will allow the electrochemical measurement of the enzyme substrate without the addition of any mediator to analyze the ET process (Zhao et al. 1992). In addition, it has been suggested that DET may proceed most easily to or from electrode surfaces when the environment is similar to the native environment of the redox protein (Zhao et al. 1992). Thus, obtaining DET between enzymes and electrode surfaces is important, once this process could be applied to the study of enzymecatalyzed reactions in biological systems and in the investigation of the mechanisms of redox reactions at enzymes molecules (Cai and Chen 2004).

The first reports of DET with a redox-active protein were published in 1977 independently by Eddowes and Hill (Eddowes and Hill 1977) and by Yeh and Kuwana (Yeh and Kuwana 1977). They showed the reversible electrochemistry, using cyclic voltammetry (CV), of cytochrome- $c$ on bipyridyl-modified gold and tin-doped indium oxide electrodes. Subsequently, in 1978/1979, 
Russian scientists reported indirect evidence that DET was also possible for larger redox proteins with enzyme activity. In this case, it was shown that laccase-modified (Berezin et al. 1978, Tarasevich et al. 1979) and peroxidase-modified (Yaropolov et al. 1979) carbon electrodes exhibit DET in the presence of their substrates.

Many redox proteins have demonstrated efficient DET reactions; however, these proteins have no intrinsic catalytic activity but act as ET components in biochemical pathways, e.g., ferredoxins and azurin (Guo and Hill 1991). On the other hand, efficient DET reactions with electrodes have been reported for few redox enzymes, e.g., GOx (Martins et al. 2014) and bilirubin oxidase (Shleev et al. 2005b). In principle, two experimental approaches could establish if DET occurs between the enzyme and the electrode surface: indirect evidence based on the catalytic response current in the presence of the substrate and direct evidence from the independent electrochemical activity of the redox cofactor in the absence of the substrate.

Many enzymes with known DET properties contain a metallocenter at the active site, e.g., heme, iron-sulfur cluster, and copper (Gorton et al. 1999), as exemplified in Figure 2a. However, there are some enzymes with DET properties that contain only an organic cofactor, such as flavin (Figure 2b) (Wilson and Turner 1992).

For DET occurrence in the redox proteins, there are some prerequisites. According to Marcus theory (Marcus 1956), the DET rate between two redox sites will depend on three factors: the reorganization energy, which is divided into the inner and outer contributions, where the first is related to the energy necessary to modify bond distances and the second is related to the energy necessary to reorganize the solvent; the potential difference between the redox centers; and the distance between the redox sites (Carter et al. 1995). Thus, ET between large redox proteins and the electrode surface is usually slow and sometimes

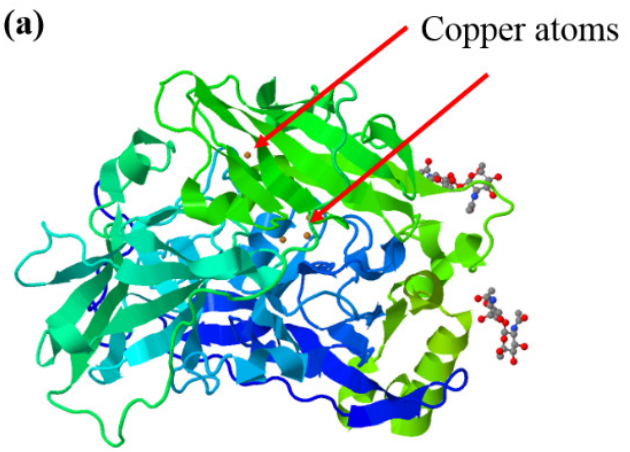

(b)

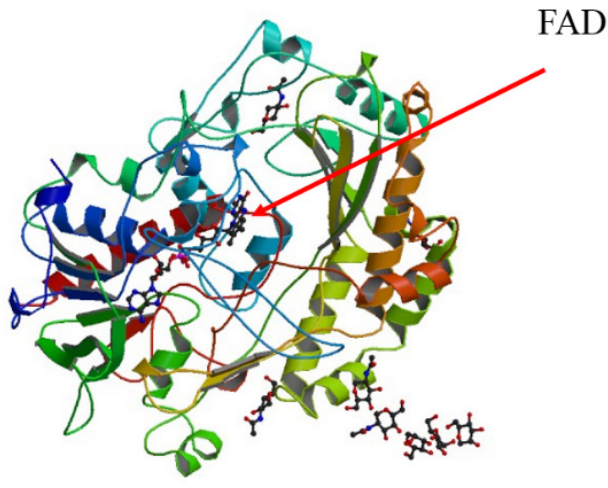

Figure 2 - Structural representation of (a) bilirubin oxidase from Myrothecium verrucaria (PDB: 2XLL) emphasizing the metallocenter, and (b) glucose oxidase from Aspergillus niger (PDB: 1CF3) emphasizing the organic cofactor.

difficult to achieve (Heller and Degani 1998) because the redox center is deeply embedded in the protein structure. As mentioned above, in many cases, a direct enzymatic electrochemical reaction is difficult because of factors such as the way in which the enzyme is adsorbed on the electrode surface, which could result in the denaturation and loss of electrochemical activity and bioactivity. Moreover, the large size of the enzyme results in the inaccessibility of the redox center, making it difficult to obtain DET (Cai and Chen 2004).

As cited above, electron tunneling from the enzymatic redox center to the electrode surface and vice versa can be described by the Marcus-HushChidsey formalism. Initially, the Marcus model was developed for homogeneous ET (Marcus 1956, Zwolinski et al. 1955) but, at the same time, Hush contributed similar ideas concerning heterogeneous ET (Hush 1958). Subsequently, Chidsey showed 
the dependence of the ET rates on distance at the electrode, and the dependence of the ET with the temperature at the metal-electrolyte interface (Chidsey 1991). Applying the Marcus-HushChidsey model to bioelectrochemistry, it is possible to conclude that the ET depends upon the enzyme structure, the position of the redox center inside the protein structure, the enzyme orientation, and the ET distance, which varies exponentially (Cooney et al. 2008). The semi-classical Marcus theory affirms that the ET rate $\left(k_{\mathrm{et}}\right)$ is governed by the Gibbs free energy $\left(\Delta G^{\circ}\right)$, the reorganization energy $(\lambda)$, and electronic coupling $\left(H_{A D}\right)$ between the electron donor (D) and acceptor (A) at the transition state. Equation 3 describes a non-adiabatic ET, which occurs for the most protein processes (Luz et al. 2014), according to Marcus theory:

$k_{E T}=\frac{4 \pi^{2} H_{D A}^{2}}{h \sqrt{4 \pi \lambda k_{b} T}} \exp \left[\frac{-\left(\Delta G^{0}+\lambda\right)^{2}}{4 \lambda k_{b} T}\right]$

Here, $h$ is the Planck constant, $k_{\mathrm{B}}$ is the Boltzmann constant, and $T$ is the temperature.

For the calculation of the ET rate constants $\left(k_{\text {oxired }}\right)$ of heterogeneous systems, it is necessary to consider the overpotential. Moreover, $k_{\text {oxired }}$ depends on the Fermi level of the electrode, and the weight of each energy state is calculated by FermiDirac statistics; thus, Equation 4 describes ET in heterogeneous systems (Chidsey 1991).

$k_{\text {red / oxi }}=\frac{k_{\max }}{\sqrt{4 \pi \lambda / \mathrm{RT}}} \int_{-\infty}^{\infty} \frac{\exp \left[-\left[\left(\lambda \pm F\left(E-E^{0^{\prime}}\right)\right) / R T-x\right]^{2} R T / 4 \lambda\right]}{\exp (x)+1} d x$

Here, $k_{\max }$ is the asymptotic value of the rate constant at high overpotential, which is given by Equation 5.

$k_{\max }=\frac{4 \pi^{2} V_{o}^{2}}{N_{A} h R T} \exp (-\beta r)$

Here, $V_{0}$ represents the degree of electronic coupling between the donor and the acceptor, $\beta$ is the decay coefficient, and $r$ is the distance between redox centers.
Thus, one possibility to improve the DET between the electrode surface and the enzyme is to shorten the distance between the active center and the electrode by modifying the electrode surface or the protein structure, as will be described in Section Protein-electrode interfaces. Another approach that has been utilized is the incorporation of nanoparticles to the electrodes (Zhang et al. 2004, Gan et al. 2004, Hilliard et al. 2002, Pereira et al. 2011). This approach is promising because nanoparticles have high specific surface areas and excellent biocompatibility and conductivity. For example, gold nanoparticles can adsorb redox enzymes without loss of the enzyme activity (Hayat 1989), and the nanoparticles act as conduction centers, facilitating the transfer of electrons. Zhao et al. 2006 showed the DET of GOx immobilized on gold nanoparticles by a Nafion film; moreover, they showed that GOx retains its electrocatalytic behavior for the oxidation of glucose.

In addition, some materials present on the electrode surface can facilitate DET, as described by Cai and Chen (Cai and Chen 2004). They found that carbon nanotubes (CNT) improve the DET of hemoglobin. This could be attributed to the oxygencontaining groups (Musameh et al. 2002) present on the CNT surface, its small size, electronic structure, and electrical conductivity.

Thus, both mediated and direct ET have advantages and disadvantages, and it is necessary to analyze the goal of the study and its applications to choose the most suitable method.

\section{PROTEIN-ELECTRODE INTERFACES}

Some parameters that govern ET can be modulated, such as the distance between the redox center of the protein and the electrode, the Fermi level of the electrode, and the protein orientation on the surface. Thus, the electrode interface plays a key role with regard to ET between the enzyme and the electrode surface. Thereby, to achieve charge transfer and 
bioelectrocatalysis of some enzymes, it is necessary to modify the electrode or protein structure. Nanoparticles, carbon nanotubes, graphene, among others have been used to modify electrode surfaces successfully. Regarding the modification in enzyme structure, deglycosylation and oligomerization procedures have been employed to improve the ET and bioelectrocatalysis.

In the case of electrode modification, "smart" materials, such as nanomaterials, have been incorporated on electrode surfaces to improve the ET. For instance, nanoparticles (Katz and Willner 2004, Xiao et al. 2003, Crespilho 2006a, b, 2008, 2009), carbon nanotubes (Azamian et al. 2002, Zhao et al. 2009), and graphene (Gao and Duan 2015, Kuila et al. 2011) have been used. Concerning nanoparticles, gold nanoparticles (AuNPs) can be functionalized with organic molecules containing thiol groups (Xiao et al. 2003, Luz and Crespilho 2016, Willner et al. 2006, 2007), and these molecules can provide wiring between the enzyme and electrode with a better protein orientation, which improves the ET. Figure 3 shows a simple method that uses the self-assembly of AuNPs, cysteine (Cys), poly(allylamine hydrochloride) (PAH), and cytochrome-c (Cyt-c) (Luz and Crespilho 2016). In this study, a AuNPmodified electrode and an unmodified electrode were studied, and it was observed that the ET was facilitated by the incorporation of the AuNPs at the protein/electrode interface. Therefore, the presence of AuNPs decreases the effective ET distance between the redox center of Cyt- $c$ and the electrode surface.

Carbon nanotubes are interesting materials for bioelectrodes because of their attractive properties, such as their inherently high surface area, tubular structure, and electrocatalytic properties (GuiseppiElie et al. 2002), which allow for effective communication between the CNTs and redox proteins. In addition, carbon nanotubes approximate a redox active center, as for cytochrome- $c$ (Davis et
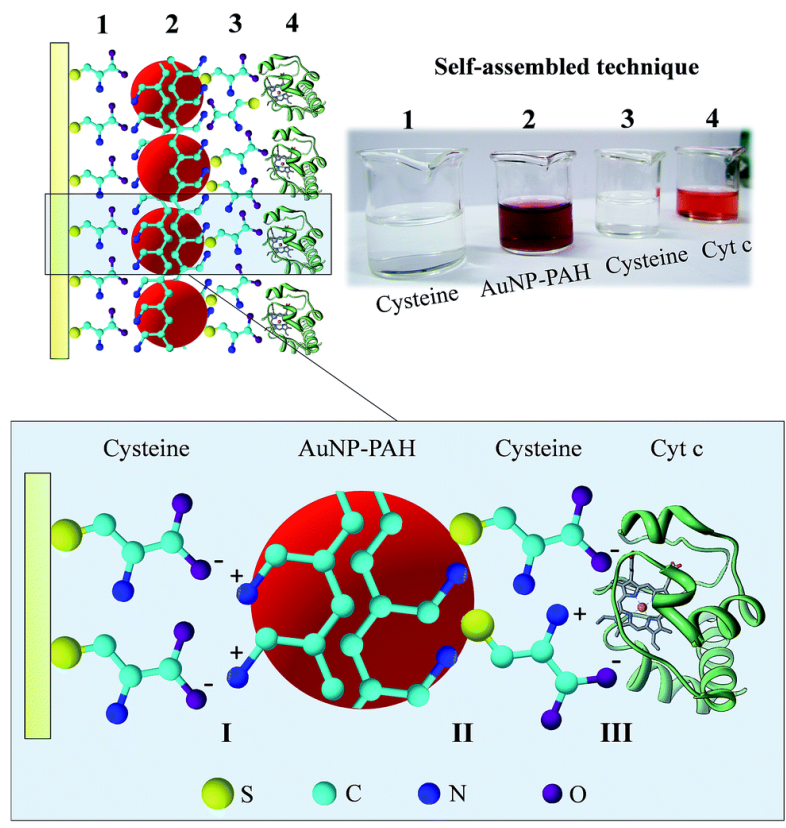

Figure 3 - Stepwise schematic illustration showing the fabrication of the $\mathrm{Au} / \mathrm{Cys} / \mathrm{AuNP}-\mathrm{PAH} / \mathrm{Cys} / \mathrm{Cyt}-\mathrm{c}$ electrode and photographs of the cysteine, AuNP-PAH, and Cyt-c solutions used to modify the electrodes. Inset: interaction sites between Cys, AuNP-PAH, and Cyt-c. Region I represents the electrostatic interactions between the carboxylic groups of cysteine and amine groups of AuNP-PAH. In region II, AuNPPAH interacts with cysteine mainly via a $\mathrm{S}-\mathrm{Au}$ bond. Region III represents the immobilization of Cyt- $c$, whose interactions with Cys are dominated by electrostatic forces between the carboxylic acid groups and $\mathrm{NH}_{3}^{+}$present in Cys and lysine residues around the edge of the heme group of Cyt-c. It is important to note that the scheme is merely illustrative and does not use a realistic length scale. Reprinted from (Luz and Crespilho 2016) with permission of Royal Society of Chemistry.

al. 1997, Wang et al. 2002a, b), and they also can be deeply embedded within a glycoprotein such as GOx (Guiseppi-Elie et al. 2002, Zhao et al. 2002). Another attractive property of carbon nanotubes is the possibility of aligning CNT assemblies on the electrode surface, wherein the length and the density of the assemblies can be controlled (Gooding et al. 2003). Graphene is another carbon nanomaterial that has been applied to enzymatic ET studies, and it has extraordinary electron transport properties (Li et al. 2008b, Zhang et al. 2005) and a very high surface area ( $\mathrm{Li}$ et al. 2008a). Graphene can promote ET in a matrix and facilitate the DET 
process between the redox center of protein and the electrode (Shan et al. 2009, Kang et al. 2009).

Other strategies to improve the ET have been used, such as the modification of surface with polymers, the functionalization of the electrode surface, the use of redox mediators, and the use of mesoporous materials and composites. Conducting and redox polymers have been applied to bioelectrodes since the 1980s (Degani and Heller 1989, Foulds and Lowe 1986, 1988, Pandey 1988) to improve the communication between the enzyme and electrode, thus resulting in fast ET. Redox mediators are used to promote effective ET because some oxidoreductases enzymes are not able to transfer electrons by themselves (Moehlenbrock and Minteer 2008). Furthermore, many lowmolecular-weight redox active compounds have been used (Chaubey and Malhotra 2002), such as methylene blue (McCord and Fridovich 1970), toluidine blue O (Boguslavsky et al. 1995), and ferrocene (Jonsson et al. 1989). Some mesoporous materials have also been used to study ET and develop biosensors (Dai et al. 2004). Composites have been studied as a platform to enhance the performance of bioelectrodes, particularly nanocomposites have been utilized to improve the amperometric response of bio-relevant molecules such as dopamine, hydrogen peroxide, or NADH (Le Goff et al. 2011).

The modification and functionalization of electrodes can improve the ET because these strategies result in the excellent adsorption of the enzyme on the electrode surface. In this context, the modification and functionalization of flexible carbon fibers (FCF) has been studied to prepare an optimal electrode for the investigation of bioelectrochemical processes (Martins et al. 2014, de Souza et al. 2016, Pereira et al. 2016, Pereira et al. 2017a, Olyveira et al. 2012b). A highperformance GDh bioanode was developed by modifying an FCF array using acid treatment with $\mathrm{H}_{2} \mathrm{SO}_{4} / \mathrm{HNO}_{3}$, which resulted in the formation of nitrated carbon nanoblisters on the FCF surface, promoting the modification and functionalization of the electrode (de Souza et al. 2016), as shown in Figure 4. This modification provided a bioelectrode with unprecedented electrocatalytic performance.

Another reported modification of FCF is their functionalization with quinone-like groups by chemical treatment with $\mathrm{KMnO}_{4} / \mathrm{H}_{2} \mathrm{SO}_{4}$ (Pereira et al. 2017a). The quinones are well-known for their ability to catalyze the oxidation of NADH (Gorton and Dominguez 2002, Katz et al. 1994, Abdellaoui et al. 2016), allowing the improvement of the bioelectrocatalysis of NAD-dependent enzymes. $\mathrm{ADH}$ was immobilized on the pristine FCF and on the FCF functionalized with quinone-like groups, and the performances of the electrodes were compared using electrochemical measurements in the presence of several ethanol concentrations, as shown in Figure 5.

As shown, after the modification of the FCF surface, there is an improvement in the bioelectrocatalysis, and the current densities increase around 10 times. This indicates that the
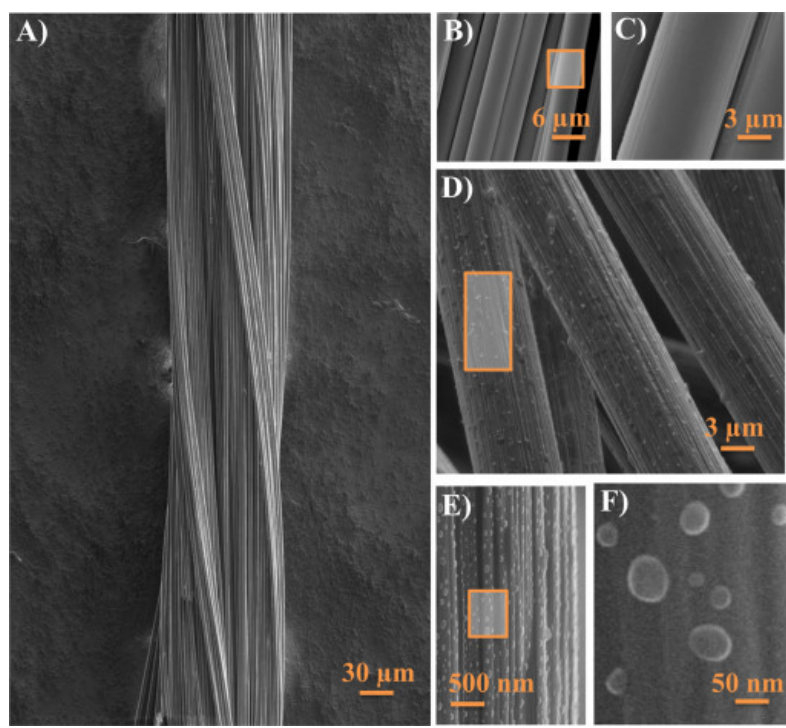

Figure 4 - (a) Pristine FCF agglomerates. (b) and (c) show the pristine FCFs at higher magnifications, (d-f) clearly showing the nitrated carbon nanoblisters (NCNBs) formed with an average size of $50 \mathrm{~nm}$ after the acid treatment. Reprinted from (de Souza et al. 2016) with permission of Elsevier. 

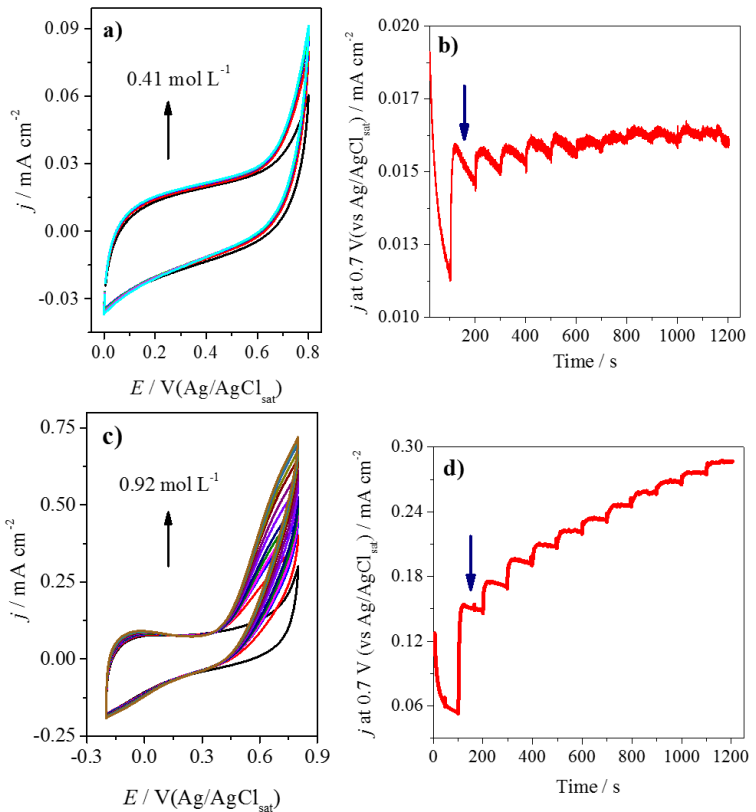

Figure 5 - (a) Cyclic voltammograms of pristine FCF-ADH and (b) the amperometric response in the presence of several ethanol concentrations using the same electrode. (c) Cyclic voltammograms of quinone modified FCF-ADH, and (d) the amperometric response for increasing ethanol concentration of the quinone-modified FCF-ADH. All measurements were carried out in $\mathrm{N}_{2}$-saturated, $0.1 \mathrm{~mol} \mathrm{~L}^{-1}$ sodium phosphate buffer ( $\mathrm{pH} 7.5$ ) containing $0.6 \mathrm{mmol} \mathrm{L}^{-1} \mathrm{NAD}^{+}$at $25^{\circ} \mathrm{C}$. For the cyclic voltammograms, the scan rate was $50 \mathrm{mVs}^{-1}$, and, for chronoamperometry, the applied potential was $0.7 \mathrm{~V}$ (vs. $\mathrm{Ag} / \mathrm{AgCl} / \mathrm{Cl}^{-}{ }_{(\text {sat) }}$ ). Reprinted from (Pereira et al. 2017a) with permission of Brazilian Chemical Society.

modification of electrode surfaces could enhance the communication between the electrode and the enzyme.

Besides the modification of the electrode surface, another possibility to improve the charge transfer is the modification of the protein structure. Mano and coauthors (Courjean et al. 2009, Prevoteau et al. 2010) showed that the deglycosylation of glycoproteins could be utilized to decrease the distance between the active center of an enzyme and the electrode surface, improving the DET. Deglycosylation corresponds to the cleavage of the glycans of the protein structure without changing the protein core (Courjean et al. 2009). The glycans are bonded to the protein backbone by glycosidic and amidic bonds, which could be cleaved by enzymatic or chemical routes. Thus, after this procedure, the enzyme could be utilized as the biocatalysts in solid electrodes with the active center closer to the surface, resulting in an increased faradaic current and improving the performance of the bioanodes in biofuel cells.

Enzymatic procedures(Courjean etal.2009) for deglycosylation usually involve exoglycosidases and endoglycosidases. The last can be divided into three main groups: endo-D, $\mathrm{H}$, and $\mathrm{F}$, which are responsible for the portions linked by asparagine; endo- $\beta$-D-galactosidase, responsible for the hydrolysis of galactosidic bonds in some prosthetic groups; and the endoglycopeptidases, which are divided into $\mathrm{N}$-glycosidases and $\mathrm{O}$-glycosidases, which hydrolyze $N$-acetylglycosamineasparagine and $\mathrm{N}$-acetylgalatosamineserine/threonine, respectively. Enzymatic routes allow for mild conditions, but they are specific for certain glycans. On the other hand, chemical methods (Patel et al. 1993, Dwek et al. 1993, Edge et al. 1981) are not specific with respect to how the glycan is bonded to the protein. Moreover, they can remove all the glycans under appropriate reaction conditions. In this case, the reactants cleave the glycosidic bonds involving mainly neutral sugars. Trifluoromethanesulfonic acid (TFMS) is a strong acid that has been utilized for the chemical deglycosylation of glycoproteins. This acid cleaves the glycosidic bonds, without changing the protein core, maintaining the enzyme activity (Edge et al. 1981). For example, for the deglycosylated horseradish peroxidase (HRP), a recombinant enzyme, it was showed a much higher rate of heterogeneous DET than for native one. In addition, the percentage of adsorbed enzyme molecules oriented for DET was increased compared to the wild-type HRP. The glycosylation could be considered as the reason for the absence of any electrochemical response of laccase from Coriolopsis fulvocinerea under anaerobic 
conditions; that is, it increases the distance of the electron tunneling between the laccase and conducting carbon (Shleev et al. 2005a). For GOx, a monolayer of the deglycosylated enzyme was immobilized on a vitreous carbon electrode, and it was observed that the electrooxidation of glucose started at $-490 \mathrm{mV}$ versus $\mathrm{Ag} / \mathrm{AgCl}$ (Courjean et al. 2009). As shown in Figure 6a, the faradaic currents relative to the $\mathrm{FAD} / \mathrm{FADH}_{2}$ cofactors inside both enzymes is much higher for the deglycosylated enzyme. By using the Laviron formalism (Laviron 1979), the rate of electron transfer obtained for GOx was found to be $0.2 \mathrm{~s}^{-1}$, while this parameter corresponds to $1.58 \mathrm{~s}^{-1}$ for the deglycosylated enzyme, indicating that, after deglycosylation, the DET is improved.

Another way to change the enzyme structure is to promote enzyme oligomerization because oligomers are more hydrophobic than native species, which improves the interaction of the enzyme with carbon electrode surfaces. Protein oligomerization can be considered as a type of protein aggregation, and it is dependent on several factors related to protein structure levels and the protein environment (Wang et al. 2010). Because the environmental conditions can influence protein oligomerization, the $\mathrm{pH}$ and hydrophobicity are considered important parameters in determining protein aggregation rates. For instance, GOx has been oligomerized using a Brønsted acid (TFMS in this case), where the $\mathrm{pH}$ of the reaction mixture was drastically reduced, exposing the hydrophobic chains of the enzyme and stabilizing its structure; consequently, the catalytic activity was retained (Pereira et al. 2017b). This oligomerized enzyme is more hydrophobic than native GOx, which improves the adsorption of the enzyme on carbon surfaces, promoting an enhancement of DET, as shown in Figure 6b. (a)

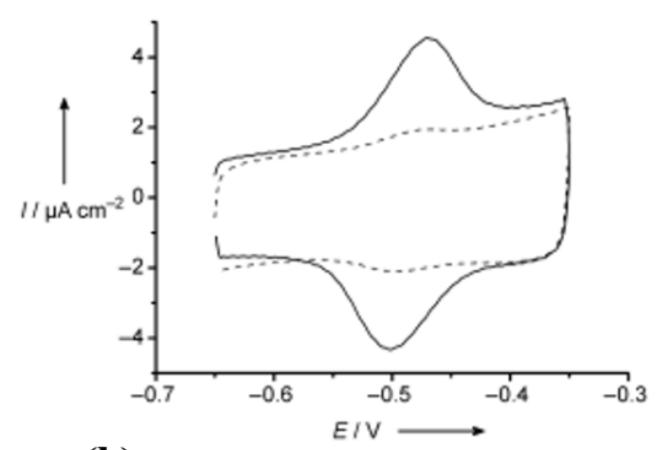

(b)

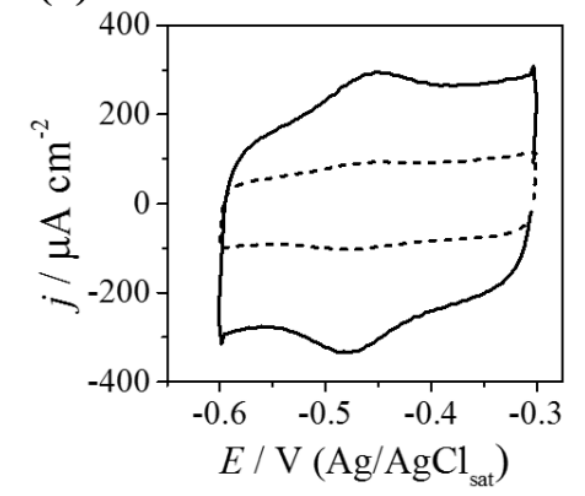

Figure 6 - (a) Cyclic voltammograms of GOx (dotted line) and deglycosylated GOx (dGOx) (solid line) adsorbed on glassy carbon electrodes $(20 \mathrm{mM}$ phosphate buffer, $\mathrm{pH} 7.4,37^{\circ} \mathrm{C}$, scan rate: $20 \mathrm{mV} \mathrm{s}^{-1}$, an argon atmosphere). Reprinted from (Courjean et al. 2009) with permission of John Wiley and Sons; (b) Cyclic voltammograms of FCF-GOx (dotted line) and FCF-Ol-GOx (solid line) bioelectrodes $(0.10 \mathrm{M}$ sodium phosphate buffer, $\mathrm{pH} 7.5,25^{\circ} \mathrm{C}$, scan rate: $100 \mathrm{mV} \mathrm{s}^{-1}$, argon atmosphere). Adapted and reprinted from (Pereira et al. 2017b). Copyright 2017 American Chemical Society.

\section{ENZYME IMMOBILIZATION}

In 1971, the term "enzyme immobilization" was coined by E. Katchalski-Katzi to designate "enzymes physically confined or localized in a certain defined region of space that retain their catalytic activity and can be used repeatedly and continuously" (Katchalskikatzir 1993). The use of immobilized enzymes in industrial processes has been of great interest since the 1960's because the anchoring of enzymes on a support facilitates the handling of the enzyme, solves the solubility 
problem of some enzymes, and minimizes or eliminates protein contamination of the product. In addition, the immobilization allows the recovery and reuse of the enzyme because of the facile separation of the biocatalyst from the product and the improvement in the enzyme stability (Klibanov 1979).

The development of biodevices, such as biosensors, implantable biodevices, and biofuel cells, requires the immobilization of enzymes on electrode surfaces. Immobilized enzymes for bioelectrochemistry have several advantages, as in industrial applications. However, some drawbacks of this approach need to be considered, for example, difficult reproducibility, greater cost, and lower catalytic activity because of limitations in the mass transfer or conformational changes.

The way that the protein is immobilized significantly affects the interactions between the electrode surface and the enzyme and the electrical communication with the redox site of the protein. Therefore, the performance of the immobilized enzyme depends on the enzyme and the method of anchoring.

The most frequently used methods for enzyme immobilization are divided into five types: noncovalent adsorption, covalent bonding, entrapment, cross-linking, and affinity (Figure 7) (Sassolas et al. 2012, Guisán 2006). The characteristics, advantages, and drawbacks are detailed in the following sections.

\section{ADSORPTION}

Immobilization by adsorption is based on physical interactions, such as van der Waals forces, hydrogen bonds, and electrostatic interactions between the support and the biomolecule (Jesionowski et al. 2014). The adsorption method involves placing the electrode in contact with the enzyme solution for a period or depositing the enzyme solution onto the electrode surface until the solvent evaporates. In

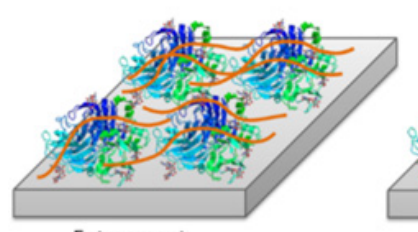

Entrapment

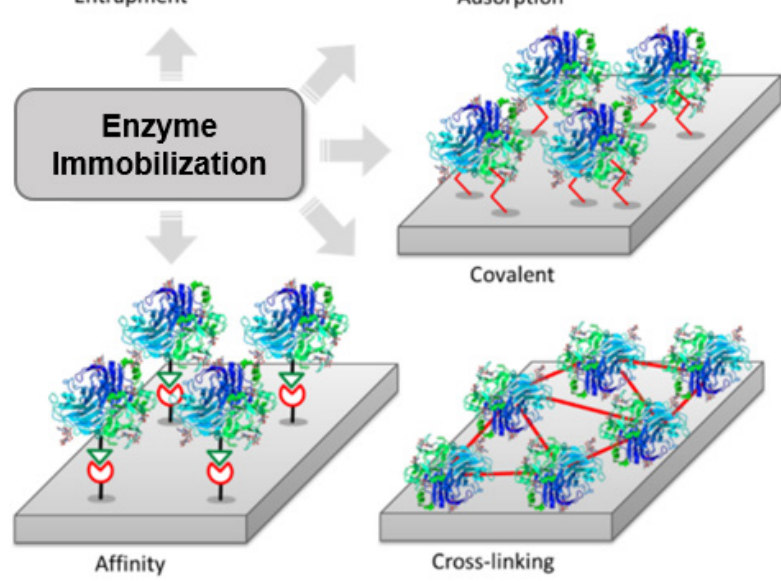

Figure 7 - Main methods of enzyme immobilization. Reprinted from (Luz et al. 2014) with permission of John Wiley and Sons.

both cases, the unadsorbed molecules are removed by washing the electrode with a buffer solution. The presence of defects on the electrode surface can improve the adsorption of enzymes, for example, defects can be easily obtained on FCF electrodes by chemical treatment with permanganate ions in sulfuric acid solution, which results in the exfoliation of the surface (Pereira et al. 2016, 2017a, Martins et al. 2014) or the treatment with sulfuric acid and nitric acid, which promotes the formation of nanoblisters on the FCF electrode surface (de Souza et al. 2016).

In addition, other attractive techniques to immobilize enzyme by adsorption are layer-bylayer (LbL) deposition and Langmuir-Blodgett (LB) adsorption (Siqueira et al. 2010). LbL is based on alternate electrostatic adsorption of layers of enzyme and an oppositely charged polyelectrolyte (Iost and Crespilho 2012). The charge of the protein is easily controlled by the $\mathrm{pH}$ of the solution, according to the isoelectric point of the biomolecule; that is, if the $\mathrm{pH}$ is higher than the isoelectric point, the enzyme is negatively charged. For immobilization 
by the LbL technique, the electrode is immersed in sequence into aqueous solutions containing the positively and negatively charged materials to be immobilized. This procedure is repeated until the desired number of layers is achieved. In contrast, the LB technique employs monolayers insoluble in water, and these LB films are transferred from the air/water interface onto electrode surface by vertical dipping into the aqueous solution. This procedure can be repeated several times to form multilayers (Iost et al. 2011b). The LbL and LB techniques have been employed for the construction of nanostructured films containing enzymes for different electrochemical applications, such as biosensing and bioelectronic devices (Iost and Crespilho 2012, Siqueira et al. 2010, Crespilho et al. 2006a, c, 2008, Iost et al. 2011b, Caseli et al. 2008).

The adsorption method is the simplest, easiest, and the most inexpensive method of enzyme immobilization onto solid surfaces. Furthermore, this method, generally, does not affect the active site of the enzyme, which contributes to the preservation of its electrocatalytic activity. However, because of the weak bonds involved, the enzyme molecules tend to leach from the electrode surface. The interactions between enzyme and electrode are destroyed by desorption forces, such as high ionic strength and $\mathrm{pH}$. Another disadvantage is that this method is non-specific; thus, it results in the immobilization of other proteins and substrates (Cao and Schmid 2005).

\section{COVALENT BONDING}

An important method of enzyme immobilization is covalent attachment because this kind of bond usually provides the strongest attachment between the enzyme and support compared to other types of enzyme immobilization, such as non-covalent adsorption. In this method, enzyme molecules are anchored to the electrode material by multiple covalent bonds between functional groups. To maintain the enzyme activity, the active site must not participate in covalent bonding.

The reactive amino acid residues should be located on the enzyme surface because access to buried residues is restricted. The most common enzyme functional groups used for covalent immobilization are the amino groups of $\mathrm{N}$-terminal amino acids and $(\varepsilon)$-amino groups of lysine residue (Cao and Schmid 2005); $\gamma$ - and $\beta$-carboxyl groups of glutamic acid and aspartic acid residues and C-terminal carboxyl groups; the guanidinyl groups of arginine residues; the sulfhydryl groups of cysteine residues; the imidazolyl group of histidine residue; the thioether moiety of methionine residue. In addition, in the case of glycosylated enzymes, covalent bonds may be formed by the sugar residues. In particular, enzymes containing cysteine residue can be directly immobilized on gold electrodes by thiol bonds.

The presence and the types of functional groups on the electrode surface are also important for covalent immobilization, and the most common functional groups are carboxylic acid groups and amino groups. The functional groups are activated by multifunctional reagents, for example, carbodiimide and glutaraldehyde. Carbodiimide can provide the linkage between amino groups of the protein and carboxylic acid groups of the electrode surface and vice versa (Figures $8 \mathrm{a}$ and $8 \mathrm{~b})$. Glutaraldehyde can be used to bond the amino groups of the support and the enzyme (Figure 8c) (Sassolas et al. 2012).

The main advantage of enzyme immobilization by covalent bonding is that the protein molecules are strongly linked to the electrode surface, which prevents the enzyme leaching, with no diffusion barrier. Multiple covalent bonds promote the rigidification of the biomolecule, reducing the conformational flexibility and thermal vibrations. This can increase the enzyme stability and prevent enzyme denaturation by heat, organic solvents, 


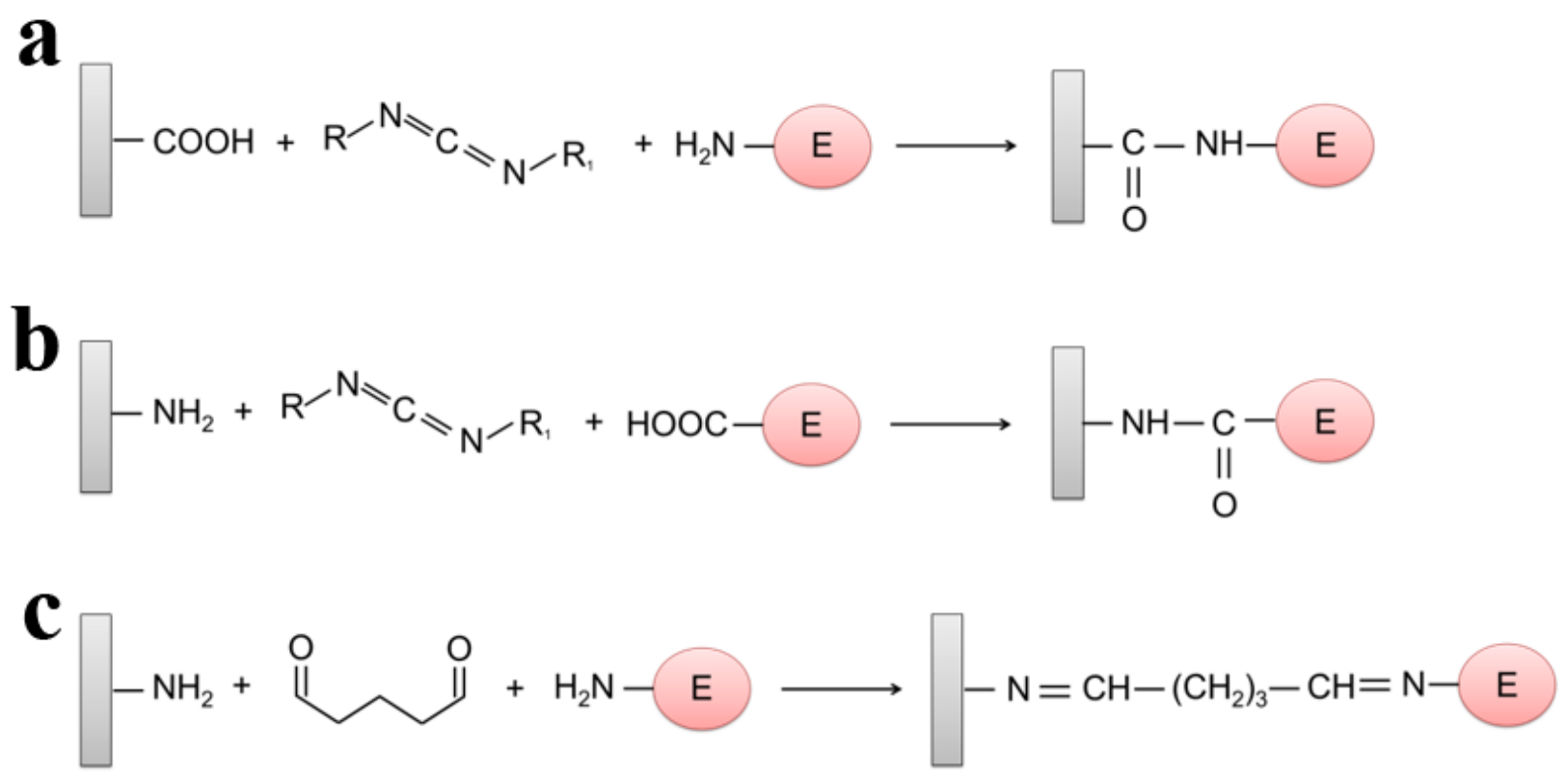

Figure 8 - Enzyme immobilization on (a) carboxylated and (b) aminated surfaces by carbodiimide coupling; (c) Enzyme immobilization on amino-functionalized surfaces by glutaraldehyde coupling.

and extreme $\mathrm{pH}$ (Mateo et al. 2007). However, the disadvantage of this immobilization method is that matrix cannot be re-used because of the irreversible attachment of the enzyme.

\section{ENTRAPMENT}

Enzymes can be easily immobilized on electrodes via their inclusion in a polymer network, such as organic or inorganic polymeric matrices. Some examples of materials used for the entrapment of enzymes are Nafion, polyacrylamide, polypyrrole, chitosan, agarose, polyaniline, and silica sol-gel (Sassolas et al. 2012, Klotzbach et al. 2008).

The method of enzyme entrapment varies according to the polymer. In the case of Nafion, two methodologies have been successfully employed: (a) the casting of a Nafion suspension on enzymes anchored on the electrode surface, thereby trapping the enzyme between the electrode and the Nafion membrane after solvent evaporation (Pereira et al. 2017a, de Souza et al. 2016) and (b) the casting of a mixture containing Nafion and enzyme on the electrode surface (Klotzbach et al. 2008). A procedure to entrap enzymes in a chitosan network is similar to that of Nafion, that is, by casting enzyme/chitosan mixture on the electrode surface (Klotzbach et al. 2008, Lee and Tsai 2009). To develop silica sol-gel-enzymebased electrodes, silica gel can be mixed with the enzyme solution and then dropped onto the electrode surface (Reddaiah and Reddy 2014). Alternatively, polypyrrole and polyaniline can be electropolymerized on the electrode surface by applying an appropriate potential or current to an electrode soaked in an aqueous solution containing the enzyme and monomer molecules. Thus, the polymer is formed on the electrode surface, and the enzyme molecules are physically incorporated into the growing polymer network (Cosnier et al. 2006).

By using the entrapment technique, several enzymes, mediators, and additives can be simultaneous immobilized within the same polymer. Furthermore, the protein activity is preserved, and the operational and storage stabilities are increased. In addition, the polymer network prevents the direct contact of the biocatalyst with the environment, which minimizes the effects of 
gas bubbles, mechanical stirring, and hydrophobic solvents. On the other hand, the main drawbacks of the entrapment immobilization method are enzyme leakage and mass transfer limitations caused by the polymer barrier (Sassolas et al. 2012, Sheldon 2007).

\section{CROSS-LINKING}

Enzyme immobilization can also be performed by cross-linking protein molecules using a bifunctional chemical cross-linker (Sassolas et al. 2012). The most used reagent for this purpose is glutaraldehyde (Barbosa et al. 2014). This dialdehyde reacts mainly with the primary amino groups of proteins; thus, the cross-linking of enzymes, either to a solid support or between protein molecules, generally implies the $\varepsilon$-amino group of lysine residues or $\mathrm{N}$-terminal group of the protein chain. Eventually, the reaction proceeds with the nucleophilic functional groups of amino acid side-chains, such as other amines, thiol, phenol, and imidazole (Habeeb and Hiramoro 1968). Co-reticulation of the target enzyme with a functionally inert protein with a high density of superficial lysine residues, such as bovine serum albumin, is quite common for the development of bioelectrodes (Olyveira et al. 2012b, Crespilho et al. 2009a).

The reaction mechanism of glutaraldehyde with proteins can proceed by several mechanisms (Figure 9). This is because glutaraldehyde assumes different monomeric and polymeric conformations in aqueous solution, and each structure can react at different points of the protein chain (Barbosa et al. 2014).

This immobilization method is simple and provides a strong interaction between the biomolecules. The cross-linking method can be combined with other enzyme immobilization methods, for example, entrapment (Olyveira et al. 2012b, Crespilho et al. 2009b). However, crosslinking has some disadvantages, such as enzyme
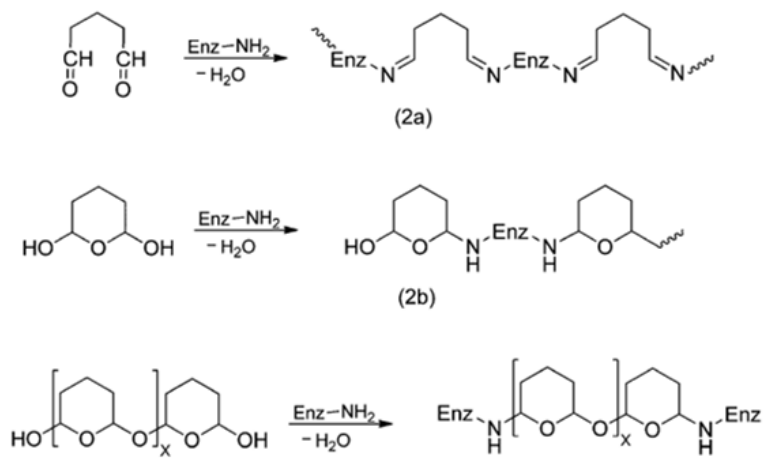

(2c)

Figure 9 - Reactions of glutaraldehyde with proteins under acidic or neutral conditions. Reprinted from (Barbosa et al. 2014) with permission of Royal Society of Chemistry.

activity losses because of distortions in the protein conformation, poor reproducibility, and low mechanical stability (Sassolas et al. 2012, Sheldon 2007).

\section{AFFINITY}

Enzymes can be immobilized on the electrode surface by (bio)affinity bonds between a specific group of the protein and the support. For this, the electrode surface must be activated, for example with lectin, avidin, or metal chelates; alternatively, the protein must be conjugated with a compound with an affinity for the support (Guisán 2006). This method has the advantage that it provides controlled and oriented immobilization of the enzyme. However, in some cases, genetic engineering may be required for the production of tagged enzymes (Sassolas et al. 2012, Datta et al. 2013).

The electrode surface can be activated by transition metal cation chelates, for example, nitrilotriacetic acid and imidodiacetic acid. In this case, enzymes containing histidine residues can be strongly attached to the surface by the interaction of these residues with the chelates (Porath et al. 1975). A drawback of this technique is that, generally, few histidine residues are accessible on the enzyme surface. Thus, genetic engineering methods are needed to produce tagged enzymes 
with histidine at specific positions. Another strategy to immobilize enzymes by affinity bonds is to exploit the strong interaction between biotin and avidin or streptavidin. For this, the biotin is bound to the enzyme through lysine residues by the reaction with biotin-ester reagents; alternatively, the enzyme can be genetically biotinylated (Guisán 2006). In addition, carbohydrates present in the surface of glycoproteins can be employed in the immobilization. Carbohydrates have a high affinity for lectins, such as concanavalin A, which can be easily immobilized on the electrode surface. This kind of immobilization is reversible and has the great advantage of using tags that are naturally present in the enzyme and located in areas of easy accessibility and are not essential for biological activity (Sassolas et al. 2012, Andreescu and Marty 2006).

\section{BIOELECTROCATALYSIS}

Electrocatalyst accelerates the rate of chemical reaction, but, in this case, the reaction takes place on the surface of an electrode (Masa and Schuhmann 2016). Electrocatalysis can also be defined as the enhancement in the electrochemical reaction rate provided by a species that is not consumed in the reaction, i.e., the electrocatalyst (Grubb 1963). When the electrode material has sites that can adsorb the reagent, the probability of achieving an energetic situation that favors ET increases significantly. Thus, materials that have this property are called electrocatalysts (Bard and Faulkner 1980). Therefore, the performance of an electrocatalyst depends on the electronic structure of the atoms on the electrode surface (Hammer and Norskov 1995, Hammer et al. 2000, Tersoff and Falicov 1981), as well the chemical nature of the surface (Chen and McCreery 1996), its morphology, and crystal structure (Lebedeva et al. 2002). An electrocatalytic cycle can be summarized by three typical steps (Masa and Schuhmann 2016): i) substrate transportation from the electrolyte bulk to the active site, ii) electrocatalytic reaction, and iii) product transportation from the catalyst surface. In step (ii), sub-reactions must be considered, which includes the substrate adsorption, ET, and product desorption.

In bioelectrocatalysis, the electrocatalysts are biomolecules, e.g., whole cells or enzymes, in particular, the enzymes of the oxidoreductase group, which catalyze redox reactions (Ghindilis et al. 1997, May 1999), and the fundamental principles are the same as for electrocatalysis. Although there are different types of oxidoreductases, the oxidases and hydrogenases are worthy of attention because they catalyze the same kind of reaction, i.e., the catalytic reactions of these enzymes start from the same substrate and finish with the same product via distinct mechanisms (Ferri et al. 2011). For instance, both GDh and GOx produce gluconolactone, as shown by Equations 1 and 6, respectively. The oxidases transfer an electron to oxygen, while the dehydrogenases transfer electrons directly to an electron acceptor molecule (a coenzyme).

glucose $+\mathrm{GOx}(\mathrm{FAD}) \rightarrow$ gluconolactone $+\mathrm{GOx}\left(\mathrm{FADH}_{2}\right)$

$\mathrm{GOx}\left(\mathrm{FADH}_{2}\right)+\mathrm{O}_{2} \rightarrow \mathrm{GOx}(\mathrm{FAD})+\mathrm{H}_{2} \mathrm{O}_{2}$

For enzyme-modified electrodes, ET between the electrode surface and the redox center of the protein is dependent on the enzyme orientation, and of the localization of the enzyme active center, which must be located at a short distance from the electrode to allow the tunneling of the electron (Heller 1992, Falk et al. 2012). Thus, the greatest challenge in bioelectrocatalysis is the development of an electrochemical interface that establishes electrical communication between the enzyme and the electrode surface (Bartlett 2008).

The activity of an enzyme as a biological catalyst often depends on the protein structure (Zoungrana et al. 1997). In other situations, the 
presence of non-protein cofactors, such as metals for metalloenzymes or organic molecules as coenzymes (McCall et al. 2000), is required. In bioelectrocatalysis, the cofactors can serve as redox centers that exchange charge between the enzyme and electrode. Usually, the cofactors are located inside the protein structure and they have high selectivity and specificity (Masa and Schuhmann 2016). Enzymes are a special group of molecular electrocatalysts (Hexter et al. 2014), and they can be attached to the electrode by numerous weak interactions. Therefore, ET between the substrate and the electrode is possible if the enzyme is suitably orientated and the enzyme active site is located a short distance from the electrode, allowing electron tunneling (Heller 1992, Falk et al. 2012). In electron tunneling in a biological process, the electrons can travel up to $14 \AA$ \& between redox centers through the protein medium under physiological conditions (Page et al. 1999); consequently, it is important that the redox centers be close to the electrode surface. In general, electrocatalysts are small molecules, such as the cobalt complex that catalyzes the hydrogen evolution reaction (Figure 10a) (McCrory et al. 2012); however, the enzymes usually utilized as biocatalysts have diameters around $100 \AA$ (Figure 10b) (Hexter et al. 2014). Thus, in most cases, there is a large distance between the enzyme's catalytic site and the protein surface, and at least one electron relay center is needed to ensure rapid intramolecular ET (as shown in Figure 10c). Fast interfacial ET between the electrode and the relay system is possible only if the enzyme makes good electronic contact with the electrode surface (Hexter et al. 2014). Figure 10d shows a pictorial model of bioelectrocatalysis, where the interfacial ET between the enzyme and the electrode is separated from the catalytic events. In other words, the bioelectrocatalysis process occurs in two steps.

In comparison to conventional catalysts, enzymes have well-defined active sites, because they are formed of a transition metal ion as a part
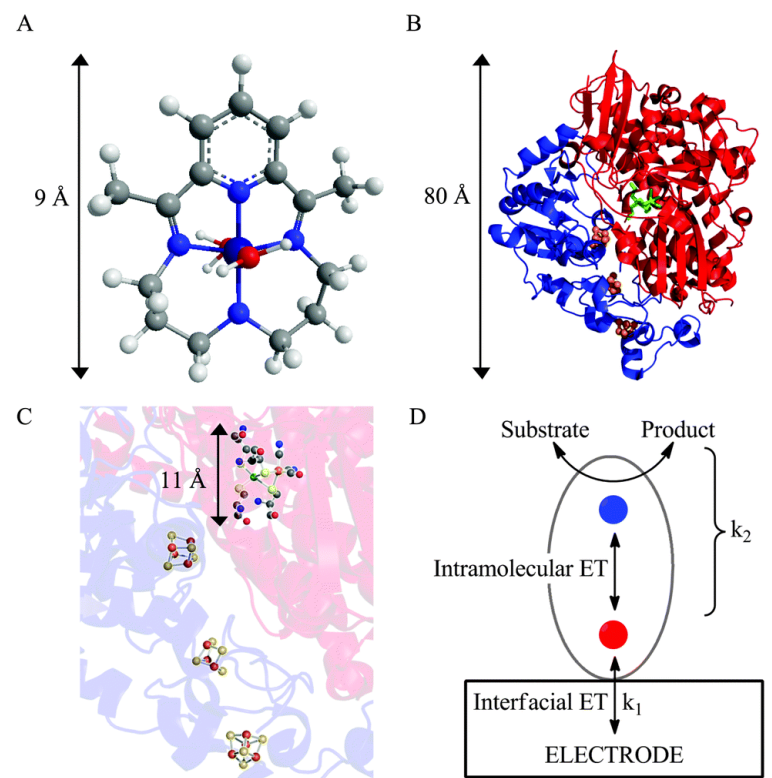

Figure 10 - (a) A molecular catalyst active in $\mathrm{H}+$ reduction. Reproduced from ref. J70. Colors represent the following atoms: Co, dark blue; N, blue; O, red; C, gray; $\mathrm{H}$, white. (b) The structure of the [NiFe]-hydrogenase from Desulfovibrio fructosovorans (PDB code 1YQ9), showing the large subunit (red) that houses the buried active site (green) and the small subunit (blue) that contains a FeS relay (orange). (c) Cutaway view of (b) showing the active site and the FeS clusters that provide an electron transfer pathway between the protein surface and the active site. Colors represent the following atoms: $\mathrm{Ni}$, green; $\mathrm{Fe}$, orange; and $\mathrm{S}$, yellow. All other atoms are colored as in (a). (d) Pictorial representation of interfacial and intramolecular electron transfer (ET) through an enzyme adsorbed onto an electrode. The red sphere represents the electrochemical control center, and the blue sphere depicts the catalytic site. Reprinted from (Hexter et al. 2014) with permission of Royal Society of Chemistry.

of the complex protein matrix. In this case, the electron densities of the redox centers are altered by the peptides and residual chemical groups present in the protein backbone to values matching the energy of substrates, allowing a faster conversion of the substrates (Masa and Schuhmann 2016).

\section{UTILIZATION OF ELECTROCHEMISTRY TO STUDY PROTEIN REDOX REACTIONS}

\section{VOLTAMMETRIC TECHNIQUES}

Once that the fundamental principles of ET processes are understood, the interest in 
bioelectrochemistry has focused on the mechanism of ET and how it is linked to other physiological functions. For small biochemical systems, the voltammetric method is a common choice, providing insight into the kinetics and thermodynamics of ET reactions. Moreover, these methods provide valuable information concerning the mechanisms and interactions of such biochemical systems (Gulaboski et al. 2012). However, for proteins, the utilization of voltammetry to understand their redox reactions is difficult because of the protein size and the presence of large lipophilic tails that prevent the transfer of electrons between the protein and the electrode.

Because the active center are often bound to internal buried sites in the secondary structure of the enzymes, access by the electrodes is difficult, which implies a slow electron exchange with the electrodes (Armstrong 1990). Consequently, early biosensors and biofuel cells utilized mediators for electrons flow. However, mediation is not the ideal approach to study fundamentals of catalytic enzyme reactions because the influence of the enzyme and the enzyme substrate on the electrochemistry of the mediator must be considered. Thus, to facilitate DET between the enzyme and the electrode surface, some types of protein thin films at the electrode surfaces have been developed (Rusling and Zhang 2001). A possible approach is so-called protein-film voltammetry (PFV) (Armstrong et al. 1997), which avoids mediation and allows the direct observation of the enzymatic ET, as well as its catalytic reaction. The concept of the PFV was developed by Fraser Armstrong and provides an important way to investigate how ET in proteins is coupled to chemical reactions, for instance, in catalysis. PFV involves co-adsorbing proteins with aminocyclitols and polymixins to give monolayers with highly reversible voltammetry utilizing an edge plane pyrolytic graphite electrode (Armstrong et al. 1997). This method solves problems such as the protein diffusion because the protein under investigation is adsorbed on the electrode, forming a stable film of enzyme molecules.

The PFV approach represents a method for studying the fundamental electrochemical of enzyme redox chemistry. In this methodology, the protein is deposited on the electrode surface mainly by self-assembly from the aqueous electrolyte in which the protein is dissolved. Thus, the redox features of the adsorbed protein can be monitored by applying a controlled potential to the proteinmodified electrode, that is, by using different voltammetric techniques (Gulaboski et al. 2012). Learning how to adsorb a protein in a native and active configuration on the electrode surface and understanding the voltammetric results on both a quantitative and qualitative level are two intrinsic challenges of PFV. Some factors make PFV an excellent technique to study the electrochemistry of different proteins. For example, the sample economy: the amount of sample required to form a monolayer is around $10^{-11} \mathrm{~mol} \mathrm{~cm}$; the sensitivity of the method: the investigation of the reactions requires a small amount of the sample; and the rate of the reaction: the voltammetric waveform and current are not limited by diffusion (Armstrong 2002).

Both cyclic voltammetry (CV) and squarewave voltammetry (SWV) can be used as powerful methods for studying redox active enzymes and proteins (Liu et al. 2005, Reeves et al. 1993, Jeuken et al. 2002), and SWV is complementary to CV. However, SWV discriminates against the charging current, extracting only the faradaic contribution of the electrochemical response. In addition, SWV can be applied for kinetic measurements because it is a fast voltammetric method. Further, this electrochemical technique is particularly attractive for the mechanistic, kinetic, and thermodynamic characterization of surface electrode processes, including those of proteins. By using sweep or cyclic voltammetry, a layer of molecules undergoing simple reversible ET gives a signal that consists of 
a pair of compact reduction and oxidation peaks, and the average value of these peaks gives the reduction potential, while their changes in shape and separation as the scan rate gives information on the ET kinetics (Armstrong 2002).

As cited above, $\mathrm{CV}$ is the most popular method for the study of thin protein film electrochemistry. For reversible electrochemical reactions, the interconversions between oxidized and reduced forms of the enzyme are fast, considering the time scale of the voltammogram. The ideal cyclic voltammogram must have symmetric oxidation and reduction peaks of equal heights and no oxidation-reduction peak separation (Bard and Faulkner 1980) The integration of the CV surface area provides the charge $(Q)$, in coulombs involved in the process, allowing the determination of the total surface concentration $\left(\Gamma_{\mathrm{T}}\right)$, in other words, the amount of the enzyme in the film (Equation 7).

$Q=n F A \Gamma_{T}$

Here, $n$ is the number of electrons transferred in the reaction, $F$ is the Faraday constant, $A$ is the electrode area in $\mathrm{cm}^{2}$, and $\Gamma_{\mathrm{T}}$ is the total surface concentration of electroactive protein in $\mathrm{mol} \mathrm{cm} \mathrm{cm}^{-2}$. The ideal reversible peak current $\left(I_{\mathrm{p}}\right)$ for a reversible thin electroactive film on an electrode is:

$I_{p}=\frac{n^{2} F^{2} A \Gamma_{T} v}{4 R T}$

where $\mathrm{R}$ is the gas constant, $T$ is the temperature in Kelvin, and $v$ corresponds to the scan rate. This model where the $I_{\mathrm{p}}$ increases linearly with increasing scan rate is ideal and is known as ideal thin-layer voltammetry (Rusling and Zhang 2001). However, the cyclic voltammograms of enzyme films are usually significantly different from predictions of an ideal thin layer model (Rusling and Zhang 2001, Rusling 2003), and these deviations depend on the enzyme and film properties. For example, the shape of the cyclic voltammogram can be unsymmetrical when only partial electrolysis of the redox sites in the films occurs during the scan.

For films where the cyclic voltammograms are controlled by diffusion, the integral under the peak is not proportional to the surface concentration of electroactive centers in the film, and this occurs because only a fraction of the protein has been electrolyzed. In this case, the peak current for an $n$-electron reaction in a film is:

$I_{p}=\left(2.69 \times 10^{5}\right) n^{3 / 2} A D_{c t}^{1 / 2} v^{1 / 2} C_{f}$

where the concentration of electroactive species $C_{\mathrm{f}}$ is equal to $\Gamma_{\mathrm{T}} / d, d$ is the film thickness, and $D_{\mathrm{ct}}$ is the charge transport diffusion coefficient (Murray 1984).

As described previously, PFV has been utilized to study systems in the absence of a substrate. However, this approach could also be used for mechanistic studies in the presence of substrate. In this case, rotating-disc voltammetry (RDV) can be used to obtain $K_{\mathrm{M}}$ and $k_{\text {cat }}$, and the limiting current $\left(I_{\mathrm{L}}\right)$ of the enzyme films in solution with the substrate is determined by the Koutecky-Levich approximation (Shaked and Whitesides 1980) (Equations 10 and 11).

$$
\begin{aligned}
& \frac{1}{I_{L}}=\frac{1}{I_{c a t}}+\frac{1}{I_{\text {Lev }}} \\
& I_{\text {Lev }}=0.62 n F A D^{2 / 3} C v^{-1 / 6} \omega^{1 / 2}
\end{aligned}
$$

Here, $C$ is the bulk concentration of the substrate, $D$ is the diffusion coefficient of the substrate, $v$ is the kinematic viscosity of the solution, and $\omega$ is the electrode rotation rate.

$I_{\text {cat }}$ in Equation 10 corresponds to the catalytic current for the enzyme reaction with the substrate, and the electrochemical form of the MichaelisMenten Equation is (Sucheta et al. 1993):

$I_{c a t}=\frac{n F A \Gamma k_{c a t} C}{\left(C+K_{M}\right)}$ 
where $\Gamma$ corresponds to the surface coverage of enzyme that can be measured by $\mathrm{CV}$, and $K_{\mathrm{M}}$ and $k_{\text {cat }}$ are the apparent Michaelis-Menten parameters.

Pulsed voltammetry can provide better sensitivity and resolution when compared to other voltammetric methods. For thin enzyme films, the square-wave voltammograms give a reversible ET with symmetric peaks resulting from subtraction of the currents measured at the end of each forward and reverse pulse. As CV, forward-reverse SWVs peaks are valuable for mechanistic analysis. However, using this method, there is no direct relation between the electroactive surface area and the integral under the curve; consequently, this parameter is better determined using $\mathrm{CV}$.

Marcus theory provides a more realistic description of enzyme thin-film voltammetry; however, using $\mathrm{CV}$, the analysis methods are less accessible than that explained above. On the other hand, using SWV, Marcus theory can be applied. In this case, non-linear regression analysis of SWV data allows the estimation of reorganization energies and the ET rate constants (Rusling et al. 2008). In addition, SWV with large amplitude pulses could be used to study more complex ET processes in multicenter enzymes with multiple redox centers (Jeuken et al. 2002).

\section{IN SITU TECHNIQUES}

Bioelectrochemical methods combined with spectroscopic techniques can provide detailed information about the activity and rate of an enzymatic process and gain direct structural insight into functionally relevant states (Ash and Vincent 2016). Vincent's group have studied metalloenzymes under direct electrochemical control by infrared (IR) spectroscopy (Healy et al. 2011, Grabarczyk et al. 2014, Ash et al. 2015). This in situ spectroelectrochemistry with IR radiation is shown in Figure 11 and is based on attenuated total reflectance (ATR) measurements, where the working electrode, modified with the protein of interest, is placed above the ATR prism (Ash and Vincent 2016, Hidalgo et al. 2015). This makes it possible to carry spectroscopic analysis under precise electrochemical control. This technique has been used in the investigation of hydrogenases that have metallic active sites, such as [NiFe] and [FeFe] hydrogenases (Ash, et al. 2017a, b, Paengnakorn et al. 2017, Healy et al. 2013). In these cases, the shifts in the $v(\mathrm{CO})$ or $v(\mathrm{CN})$ vibrational bands are monitored, allowing the identification of short-lived intermediates, the diagnosis of redox-coupled structural changes, and the monitoring of side reactions. Furthermore, some potential-dependent changes can be observed in bands associated with dehydrogenase active site ligands. This spectroelectrochemical method has also been used to study a [MoFe] nitrogenase (Paengnakorn et al. 2017), demonstrating the versatility of this approach.

Another vibrational spectroscopy technique for monitoring in situ bioelectrochemical systems is Raman spectroscopy, where surface enhanced resonance Raman spectroscopy is used to improve the signal (Silveira et al. 2015, Sezer et al. 2011, Ly et al. 2011). Electronic spectra have also been used in the study of bioelectrochemical reactions, for example, the UV-vis spectroelectrochemical technique was used in the evaluation of ferredoxin from Schizosaccharomyces pombe (Wu et al. 2011), where several electronic spectra at various applied potentials were obtained for this protein. Fluorescence spectroelectrochemistry is another method that is based on electronic transitions, and this technique was used for the simultaneous monitoring of the type-1 copper oxidation state and the nitrite turnover rate of a nitrite reductase (NiR) from Alcaligenes faecalis S-6 (Krzeminski et al. 2011). Fluorescence spectroelectrochemical methods were also applied in the study of azurin, involving the direct observation of both kinetic and thermodynamic dispersion in a protein film on an electrode surface at the molecular scale (Salverda 


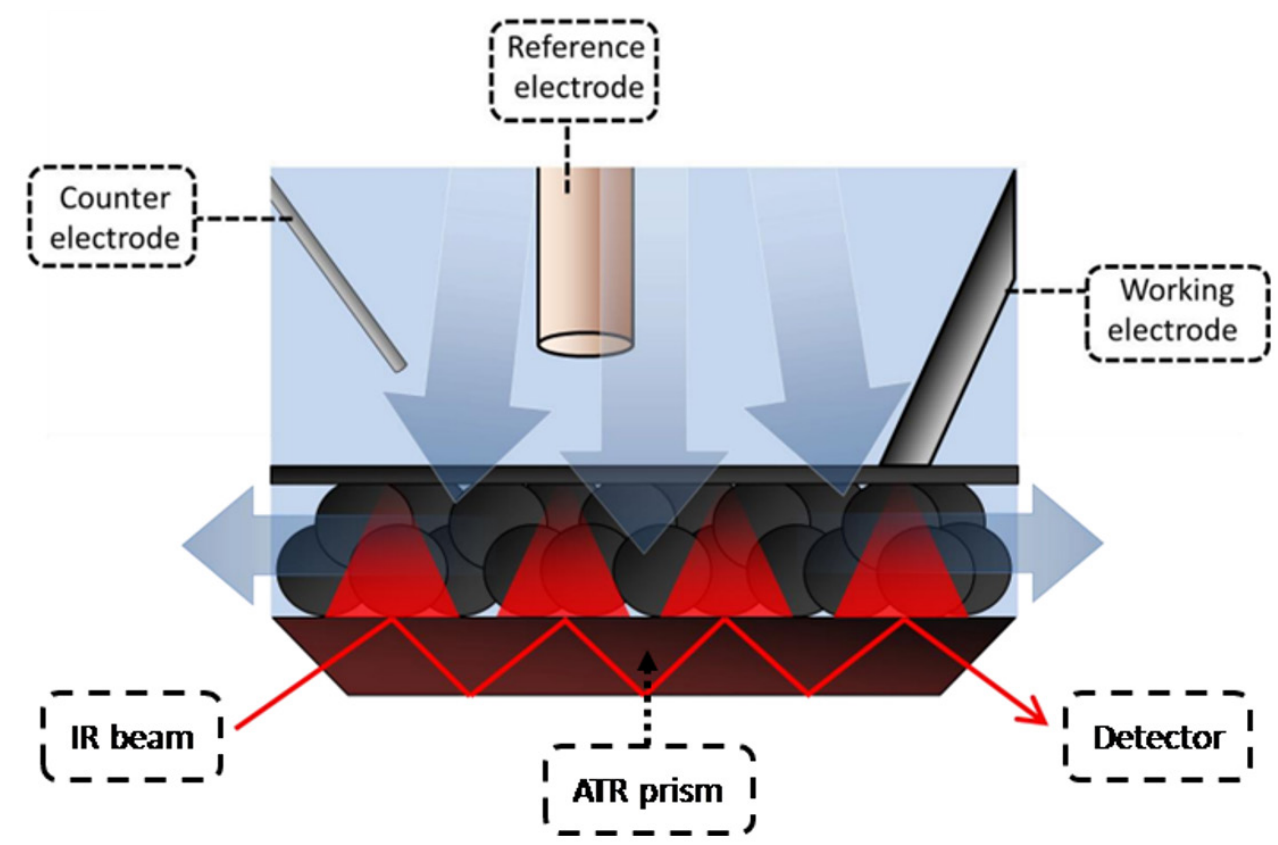

Figure 11 - Schematic representation of the spectroelectrochemical ATR-IR cell designed for protein film infrared electrochemistry experiments, showing the relative location of electrodes and the direction of solution flow. The enzyme, Hyd-1, is adsorbed on carbon beads which are cast directly onto the $\mathrm{Si}$ internal reflection element. Adapted and reprinted from (Hidalgo et al. 2015) with permission of John Wiley and Sons.

et al. 2010). This approach is based on redoxdependent absorbance changes, which can be monitored in the fluorescence domain by means of a Förster resonance energy transfer (FRET) donoracceptor pair, whereby the redox site is the energy acceptor and an externally linked dye label is the fluorescent donor (Krzeminski et al. 2011, Salverda et al. 2010). Lastly, another in situ technique is based on magnetic spectroscopy, where magnetic circular dichroism is used for the evaluation of the proteins with in situ control of electrochemical potential (Marritt et al. 2006). This methodology was utilized in the analysis of the redox behavior of the cytochrome- $c$, a hemoprotein. The technique was demonstrated to be a robust analytical tool for the determination of heme properties in multiheme enzymes (Marritt et al. 2006).

The most recent techniques for studying bioelectrochemical processes, by using in situ techniques, are the differential electrochemical mass spectrometry (DEMS) (de Souza et al. In
Press) and potentiometric titrations combined with electron paramagnetic resonance (Artz et al. In Press). The DEMS technique was applied in the study of the bioelectro-oxidation of ethanol by $\mathrm{ADH}$, and allows the concomitantly detection of the two substrates (NADH and acetaldehyde) by using electrochemical and mass spectrometric techniques on-line. This new technique can be useful for other redox enzymes when their products are gaseous or volatile. The scheme of DEMS setup and the bioelectrohemical cell are represented in figure $12 \mathrm{a}$ and $12 \mathrm{~b}$. This system is composed by a conventional electrochemical cell connected in a mass spectrometer and the bioelectrochemical cell had an FCF with immobilized ADH as working electrode, the electrical contact was provided by a gold ring and wire, and the working electrode is supported over a polytetrafluoroethylene (PTFE) membrane that allows only the passage of gaseous and volatile compounds. 
a)

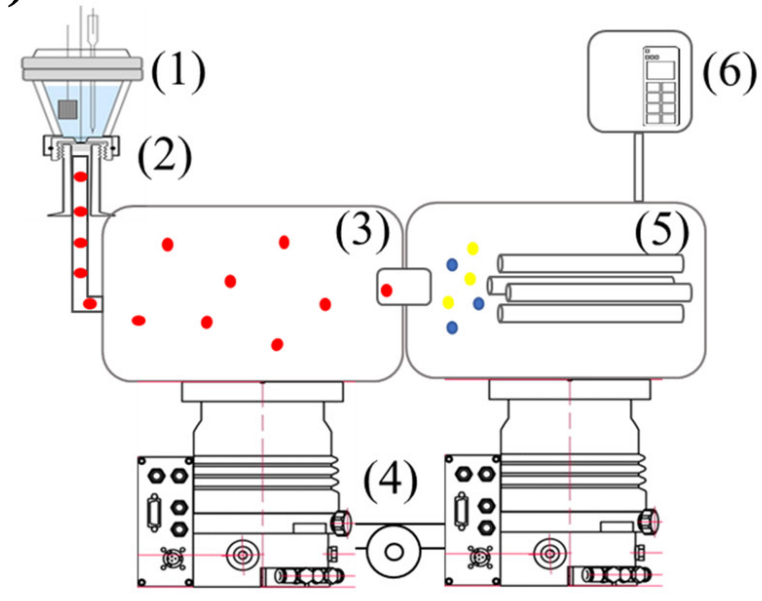

b)

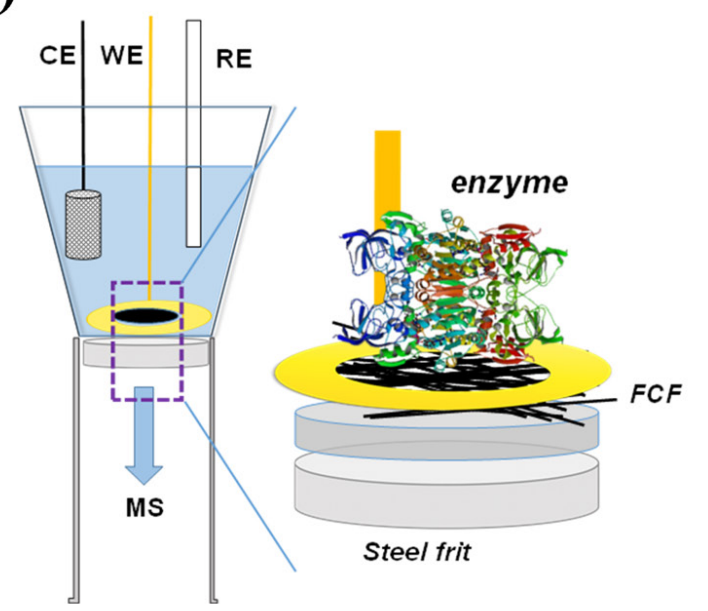

Figure 12 - (a) DEMS setup: (1) electrochemical half-cell, (2) connection between electrochemical half-cell and mass spectrometer, (3) pre-vacuum chamber, (4) turbomolecular vacuum pumps, (5) quadrupole, and (6) controller. The red spheres represent volatile compounds, and the blue and yellow ones are the ionized fragments. (b) Zoomed area between 1 and 2, where CE is the counterelectrode, WE is the working electrode, the black region is FCF with the immobilized ADH, the yellow portion is a gold electrical connection, and $\mathrm{RE}$ is the reference electrode $\left(\mathrm{Ag} / \mathrm{AgCl} / \mathrm{Cl}^{-}{ }_{\text {sat }}\right)$. The interface is constituted by a polytetrafluoroethylene (PTFE) membrane over a steel frit. Figure 12b was reprinted from (de Souza et al. In Press) with permission of Royal Society of Chemistry.

\section{APPLICATIONS: BIOSENSORS AND BIOFUEL CELLS}

In addition to answer fundamental questions about the ET processes in biological systems involving macromolecules, whole cells, and membranes, bioelectrochemistry has a wide range of practical applications, such as in biosensors, immunoassays, energy conversion, wastewater treatment, and bioelectrosynthesis (Bartlett 2008, Olyveira et al. 2012a). As the present review addresses the bioelectrochemistry of enzymes, we will describe the main applications of enzymatic devices, such as biosensors and biofuel cells (BFCs). These biodevices have been successfully used in numerous areas, ranging from environmental monitoring to in vivo energy harvesting.

\section{ENZYMATIC BIOSENSORS}

Enzymatic biosensors are analytical devices that use enzymes to detect and/or quantify specific chemicals. The selective analysis provided by these devices is based on biochemical molecular recognition. Because of their specificity, portability, fast response, and low cost, enzymatic biosensors are present in many different fields, such as food quality control, the monitoring of industrial processes and pollutants, and biomedical analyses (Iost et al. 2011a, Oliveira et al. 2014, Luz et al. 2013). A major application of biosensors is in blood glucose monitoring for the management of diabetes. Glucose biosensors are commercially available and account approximately $85 \%$ of the world market for biosensors. Most personal blood glucose monitors are based on disposable, screenprinted enzyme electrode strips. Each strip contains printed working and reference electrodes, where the working electrode coated with the necessary reagents (enzyme, mediator, stabilizer, surfactant, linking, and binding agents) are deposited in a dry form (Turner 2013).

The first glucose enzyme electrode was reported in 1962 by Clark and Lyons. They used GOx, and the measurements were based on monitoring the consumed oxygen. As discussed, GOx catalyzes 
the oxidation of glucose to gluconolactone. In the presence of $\mathrm{O}_{2}$, the natural $\mathrm{GOx}$ electron acceptor, the oxidized form of the enzyme, GOx-FAD, is regenerated and oxygen and hydrogen peroxide are produced (Equation $6 \mathrm{~b}$ ).

Glucose concentration can be indirectly determined by the amperometric monitoring of hydrogen peroxide. This product is easily oxidized to molecular oxygen at a platinum electrode, according to Equation 13, and glucose biosensors based on the measurement of hydrogen peroxide are known as first-generation biosensors (Wang 2008).

$$
\mathrm{H}_{2} \mathrm{O}_{2} \rightarrow \mathrm{O}_{2}+2 \mathrm{H}^{+}+2 \mathrm{e}^{-}
$$

Although the measurement of the formed peroxide is simple, this kind of biosensor is subject to errors that are attributed to fluctuations in oxygen tension, the stoichiometric oxygen limit, and the presence of interferers in the blood (Wang 2008). To overcome these problems, efforts have focused on the replacement of oxygen by nonphysiological electron acceptors, redox mediators, for secondgeneration glucose biosensors. Ferrocene derivatives, ferricyanide, conducting organic salts, quinones, transition-metal complexes, phenothiazines, and phenoxazines have all been used as redox mediators for GOx. Using mediators, glucose measurements become independent of oxygen pressure, and interfering reactions are minimized (Wang 2008).

The most recent glucose biosensors based on GOx have eliminated redox mediators (thirdgeneration glucose biosensors). In this case, the electrons are transferred directly from the redox site of the enzyme to the electrode at potentials very close to the redox potential of the enzyme. Thus, biosensors with high selectivity are obtained in a simpler and cleaner system (Wang 2008). However, the development of GOx-based electrodes that involve DET and show high performance is not trivial and, usually, new electrode materials are required to enhance the enzyme-electrode electronic communication. Recently, the DET of GOx adsorbed on FCF electrodes modified with graphene oxide was reported. In this case, the authors demonstrated that the presence of graphene oxide at the enzyme/electrode interface decreases the distance between the $\mathrm{FAD} / \mathrm{FADH}_{2}$ enzyme cofactor and the FCF surface (Figure 13) (Martins et al. 2014). Another way to obtain a clear DET between GOx and the electrode and to improve the electrocatalytic response is by modifying the enzyme structure. For example, the controlled oligomerization of GOx by treatment with a Brønsted acid can be used to provide a more efficient biocatalyst (Pereira et al. 2017b).

Current efforts concerning the development of glucose biosensors have focused on implantable biodevices. In vivo glucose monitoring can eliminate
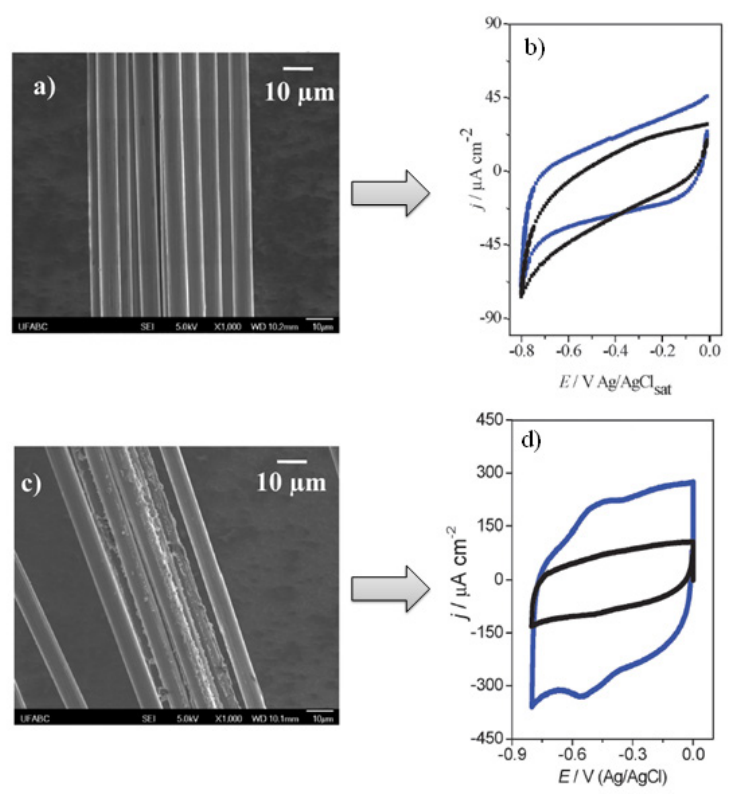

Figure 13 - Field emission-scanning electron microscope images of the FCF (a) and graphene oxide-modified fibers (c). Cyclic voltammograms of (b) FCF and (d) graphene oxidemodified fibers before GOx immobilization (black lines) and after enzyme immobilization (blue lines). Scan rate: $30 \mathrm{mV}$ $\mathrm{s}^{-1}$. Adapted and reprinted from (Martins et al. 2014) with permission of Royal Society of Chemistry. 
the inconvenience associated with standard fingerstick sampling. Moreover, an implanted glucose biosensor can provide continuous monitoring of glucose in real time and with high accuracy (Wang 2008). The development of implantable biosensors requires biocompatible and miniaturized systems, and these characteristics can be easily achieved by using FCF-based electrodes. Iost et al. (2015) reported an implantable biochip based on GOx and a neutral redox mediator immobilized on the surface of FCF (Figure 14). This material enables the biochip to be conveniently manipulated during insertion into the jugular vein of a living rat. The ability for in vivo glucose detection was evaluated with a normal concentration of glucose and with diabetic simulation. In this case, the biochip showed promise performance for future applications of implantable bioelectronics devices.

\section{ENZYMATIC BIOFUEL CELLS}

Similar to fuel cells, BFCs are electrochemical devices that convert the free energy of a chemical reaction into electrical power for the purpose of doing work (Bartlett 2008). BFCs have been classified as either microbial-based and enzymatic fuel cells according to the location of the enzymes, which can be inside of microorganisms or outside of living cells. However, microbial-based biofuel cells are outside the scope of this review and will not be discussed here.

Enzymes show remarkable advantages over conventional inorganic catalysts, such as biocompatibility. In addition, they are less expensive than precious metal catalysts and show higher efficiency, higher selectivity, and higher activity under mild conditions (room temperature and near-neutral $\mathrm{pH}$ ). The selectivity of enzymes for some substrates can simplify the design of BFCs because the separation of fuel and oxidant by a membrane is not necessary. These features make enzymatic BFCs attractive alternatives to rechargeable batteries and traditional fuel cells.

BFCs can be constructed by several different approaches. The advantage of enzymatic BFCs

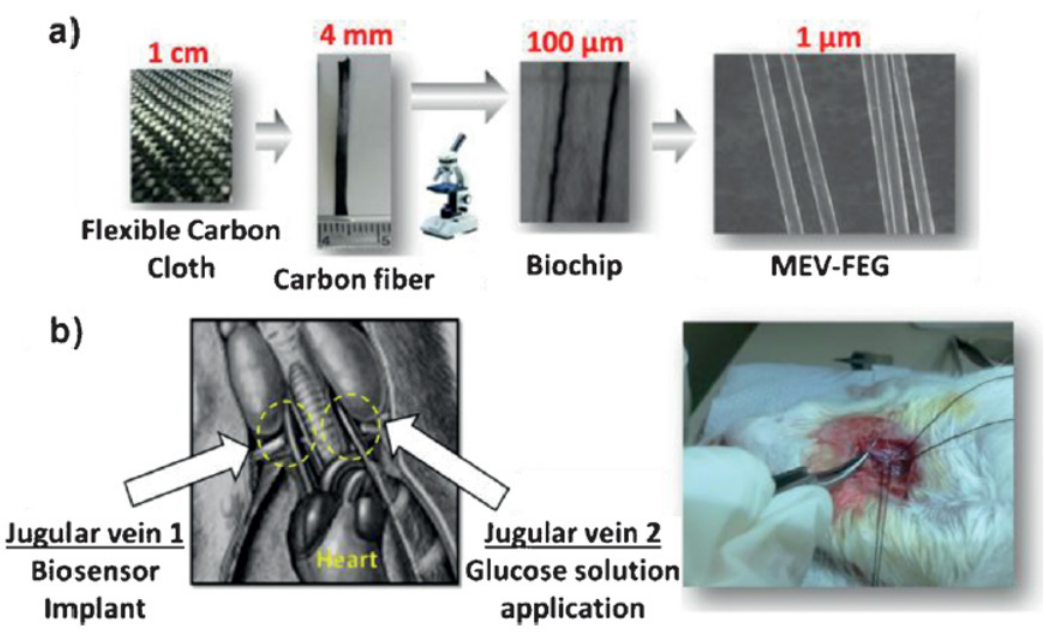

Figure 14 - (a) Photograph of the prepared device implanted in a rat vein. From left to right, carbon cloth and the micromanipulation of a single FCF using an optical microscope to obtain the biochip in a millimeter catheter are presented. The SEM image shows a more detailed visualization of the CF dimensions. (b) Left: Schematic representation of the local implanted biochips in jugular rat veins 1 and 2. Right: Photograph of the implanted FCF microelectrodes in the jugular rat veins (Rattus novergicus). Reprinted from (Iost et al. 2015) with permission of John Wiley and Sons. 
is the capability to produce biodevices much smaller than microbial cells of equivalent power. Furthermore, this type of cell allows operation closer to the redox potential of the enzyme (Ivnitski et al. 2006). Enzymatic BFCs utilize purified enzymes as catalysts for the oxidation or reduction of metabolites at the anode or the cathode, respectively (Cooney et al. 2008).

The general operation of an enzymatic BFC consists of two separate redox reactions that occur at electrodes modified with enzymes and connected to an external circuit (Figure 15) (Luz et al. 2014). However, the main limiting factor in these systems is the inefficient generation of current at the anode. The current densities at enzyme-functionalized anodes depends on the loading of the enzyme immobilized on the electrode per unit area and the rates of the two reactions; that is, the turnover of the substrate by the enzyme working at the anode and the transfer of electrons from the active sites of the enzyme to the electrode surface (Davis and Higson 2007). In addition, the heterogeneous ET rate constant of the enzyme is influenced by the support material, immobilization method, and target working enzyme. Thus, the observed maximum current density is usually limited by the inefficient ET between the enzyme active sites and the electrode surface.

For the efficient operation of an enzymatic BFC, some conditions must be satisfied: the enzyme should have high catalytic activity and stability, the anode should have a redox potential as negative as possible to achieve the maximum potential difference between the anode and the cathode, and, for bioelectrocatalysis, a suitable mediator and enzyme immobilization methodology for the efficient ET between the active center of the enzyme and the electrode surface must be found (Ivnitski et al. 2006).

The first enzymatic BFC was reported in 1964 using GOx immobilized at the anode and glucose as the fuel (Yahiro et al. 1964). Despite the advances in this type of cell, their performances in terms of power density, lifetime, and operational stability are still worse than those of chemical fuel cells. For many years, GOx has been utilized to develop powerful enzyme-based bioanodes, but their utilization brings some issues because it is necessary to use a membrane in a BFC with this enzyme because oxygen is present in the cathode compartment, which interferes with GOx (Sales et al. 2013). Thus, recently, some other enzymes have been utilized as the anodes of BFCs, such as GDh (de Souza et al. 2016) and ADH (Pereira et al. 2017a). ADH is used to study the catalytic reversible interconversion of alcohols and aldehydes or ketones, while the GDh NAD ${ }^{+}$-dependent enzyme is advantageous because it is unaffected by the presence of molecular oxygen. Thus, a membrane dividing the cell into two chambers is not required; this is an important characteristic for implantable systems (Sales et al. 2013).

In recent years, the development of enzymatic BFCs has resulted in biodevices operating in living organisms that use organic compounds available in the host organism as fuel, mainly glucose. BFCs have been implanted in fruits (Katz et al. 2001, Chen et al. 2001), rats (Cinquin et al. 2010, Zebda et al. 2013, Sales et al. 2013), rabbits (Miyake et al. 2011), cockroaches (Rasmussen et al. 2012), snails (Halamkova et al. 2012), clams

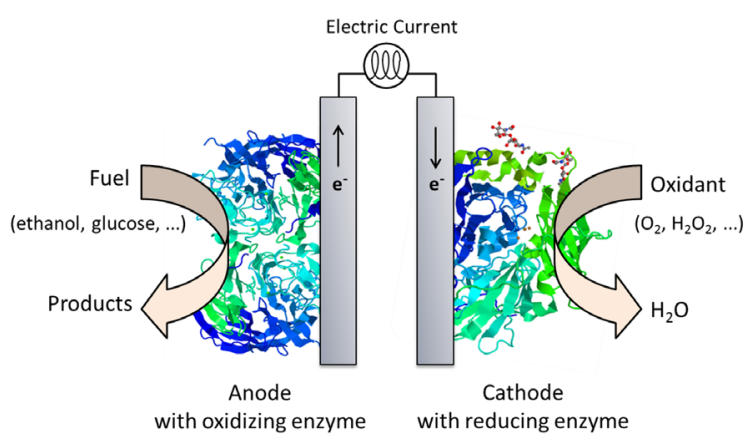

Figure 15 - Representative scheme of an enzyme based biofuel cell. Reprinted from (Luz et al. 2014) with permission of John Wiley and Sons. 
(Szczupak et al. 2012), and lobsters (MacVittie et al. 2013). Enzymatic BFCs implanted in small animals could contain wireless transmitting devices for military, industrial, and environmental monitoring (MacVittie et al. 2015). In mammals, these implantable biodevices have biomedical applications, such as the supply of power to cardiac pacemakers and artificial organs (Falk et al. 2013).

\section{CONCLUSIONS}

In this review, we have addressed the main theoretical and practical aspects of the bioelectrochemistry of redox proteins. The advances in enzyme catalysis in films and the development of new materials, such as metal nanoparticles, carbon nanotubes, flexible carbon fibers, and graphene, have improved the protein-electrode interactions and allowed the study of electron transfer and the bioelectrocatalytic mechanisms of several enzymes directly. The development of new methodologies and in situ techniques have allowed us to obtain molecularlevel detail, which has contributed to the elucidation of fundamental aspects of electron transfer in biomolecules and bioelectrocatalytic mechanisms. Moreover, these developments, combined with constant efforts toward the improvement in the performance, stability, biocompatibility, and miniaturization of bioelectrochemical systems, have contributed to the development of biodevices for biosensing and energy conversion.

Therefore, future developments in bioelectrochemistry depend on its integration with other areas, such as nanotechnology, solid state physics, surface chemistry, bioengineering, biology, medicine, and electrical engineering, to elucidate other theoretical issues and increase practical applications.

\section{ACKNOWLEDGMENTS}

The authors gratefully acknowledge financial support from Fundação de Amparo à Pesquisa do
Estado de São Paulo (FAPESP) (F.N.C.; project numbers 2015/16672-3, 2013/14262-7), Conselho Nacional de Desenvolvimento Científico e Tecnológico (CNPq) (F. N. C.; project number 307397/2016-5). A. R. P. and G. C. S acknowledge FAPESP doctoral fellowship numbers 2013/199082 and 2015/22973-6, respectively.

\section{REFERENCES}

ABDELLAOUI S, MILTON RD, QUAH T AND MINTEER SD. 2016. NAD-dependent dehydrogenase bioelectrocatalysis: the ability of a naphthoquinone redox polymer to regenerate NAD. Chem Commun 52: 11471150.

ALKIRE RC, KOLB DM AND LIPKOWSKI K. 2011. Bioelectrochemistry: fundamentals, applications and recent developments. New Jersey: Wiley-VCH, 411 p.

ANDREESCU S AND MARTY JL. 2006. Twenty years research in cholinesterase biosensors: From basic research to practical applications. Biomol Eng 23: 1-15.

ARMSTRONG FA. 1990. Probing metalloproteins by voltammetry. Struct Bonding 72: 137-230.

ARMSTRONG FA. 2002. Insights from protein film voltammetry into mechanisms of complex biological electron-transfer reactions. J Chem Soc Dalton Trans 5: 661-671.

ARMSTRONG FA, HEERING HA AND HIRST J. 1997. Reactions of complex metalloproteins studied by proteinfilm voltammetry. Chem Soc Rev 26: 169-179.

ARMSTRONG FA, HILL HAO AND WALTON NJ. 1982. Direct electrochemical oxidation of Clostridium pasteurianum ferredoxin: identification of facile electrontransfer processes relevant to cluster degradation. FEBS Lett 150: 214-218

ARTZ JH ET AL. IN PRESS. The reduction potentials of [FeFe]-hydrogenase accessory iron-sulfur clusters provide insights into the energetics of proton reduction catalysis. J Am Chem Soc.

ASH PA ET AL. 2017a. Generating single metalloprotein crystals in well-defined redox states: electrochemical control combined with infrared imaging of a $\mathrm{NiFe}$ hydrogenase crystal. Chem Commun 53: 5858-5861.

ASH PA, HIDALGO R AND VINCENT KA. 2017b. Proton Transfer in the Catalytic Cycle of [NiFe] Hydrogenases: Insight from Vibrational Spectroscopy. ACS Catal 7: 24712485.

ASH PA, LIU J, COUTARD N, HEIDARY N, HORCH M, GUDIM I, SIMLER T, ZEBGER I, LENZ O AND VINCENT KA. 2015. Electrochemical and Infrared Spectroscopic Studies Provide Insight into Reactions of 
the NiFe Regulatory Hydrogenase from Ralstonia eutropha with $\mathrm{O}_{2}$ and CO. J Phys Chem B 119: 13807-13815.

ASH PAAND VINCENT KA. 2016. Vibrational spectroscopic techniques for probing bioelectrochemical systems. Adv Biochem Eng/Biotechnol 158: 75-110.

AZAMIAN BR, DAVIS JJ, COLEMAN KS, BAGSHAW CB AND GREEN MLH 2002. Bioelectrochemical singlewalled carbon nanotubes. J Am Chem Soc 124: 1266412665.

BANKAR SB, BULE MV, SINGHAL RS AND ANANTHANARAYAN L. 2009. Glucose oxidase - An overview. Biotechnol Adv 27: 489-501.

BARBOSA O, ORTIZ C, BERENGUER-MURCIA A, TORRES R, RODRIGUES RC AND FERNANDEZLAFUENTE R. 2014. Glutaraldehyde in bio-catalysts design: a useful crosslinker and a versatile tool in enzyme immobilization. RSC Adv 4: 1583-1600.

BARD AJ AND FAULKNER LR. 1980. Electrochemical methods: fundamentals and applications. New York: Wiley, $864 \mathrm{p}$.

BARD AJ, STRATMANN M AND WILSON GS. 2002. Encyclopedia of electrochemistry: bioelectrochemistry: Vol. 9. New Jersey: Wiley VCH, 672 p.

BARTELS P, ZHOU A, ARNOLD A, NUNEZ N, CRESPILHO F, DAVID S AND BARTON J. 2017. Electrochemistry of the [4Fe4S] Cluster in Base Excision Repair Proteins: Tuning the Redox Potential with DNA. Langmuir 33: 2523-2530.

BARTLETT P. 2008. Bioelectrochemistry: fundamentals, experimental techniques and applications. New Jersey: J Wiley \& Sons, 494 p.

BARTLETT PN, TEBBUTT P AND WHITAAKER RG. 1991. Kinetic aspects of the use of modified electrodes and mediators in bioelectrochemistry. Prog React Kinet 16: 55-155.

BEINERT H, HOLM RH AND MÜNCK E. 1997. Ironsulfur clusters: nature's modular, multipurpose structures. Science 277: 563-569.

BEREZIN IV, BOGDANOVSKAYA VA, VARFOLOMEEV SD, TARASEVICH MR AND YAROPOLOV A. I. 1978. Bioelectrocatalysis. Equilibrium oxygen potential in the presence of laccase. Dokl Akad Nauk 240: 615-618.

BERNSTEIN EM. 2008. Bioelectrochemistry research developments. UK: Nova Science Publishers, 239 p.

BEYENAL H AND BABAUTA JT. 2015. Biofilms in bioelectrochemical systems: from laboratory practice to data interpretation. New Jersey: Wiley, 416 p.

BOGUSLAVSKY LI, GENG L KOVALEV IP, SAHNI SK, XU Z AND SKOTHEIM TA. 1995. Amperometric thinfilm biosensors based on glucose dehydrogenase and toluidine blue $\mathrm{O}$ as catalyst for NADH electrooxidation. Biosens Bioelectron 10: 693-704.
BRDICKA R. 1933. Polarographic studies with the dropping mercury kathode. Part XXXI. A new test for proteins in the presence of cobalt salts in ammoniacal solutions of ammonium chloride. Collect Czech Chem Commun 5: $112-128$.

CAI CX AND CHEN J. 2004. Direct electron transfer and bioelectrocatalysis of hemoglobin at a carbon nanotube electrode. Anal Biochem. 325: 285-292.

CAO L AND SCHMID RD. 2005. Carrier-bound immobilized enzymes: principles, application and design. New Jersey: Wiley VCH, $578 \mathrm{p}$.

CARDOSI MF AND TURNER APF. 1987. Biosensors: fundamentals and applications. Oxford: Oxford University Press, 786 p.

CARTER MT, ROWE GK, RICHARDSON JN, TENDER LM, TERRILL RH AND MURRAY RW. 1995. Distance dependence of the low-temperature electron-transfer kinetics of (ferrocenylcarboxy)-terminated alkanethiol monolayers. J Am Chem Soc 117: 2896-2899.

CASELI L, CRESPILHO FN, NOBRE TM, ZANIQUELLI MED, ZUCOLOTTO V AND OLIVEIRA ON. 2008. Using phospholipid Langmuir and Langmuir-Blodgett films as matrix for urease immobilization. J Colloid Interface Sci 319: 100-108.

CHAUBEY A AND MALHOTRA BD. 2002. Mediated biosensors. Biosens Bioelectron 17: 441-456.

CHEN PH AND MCCREERY RL. 1996. Control of electron transfer kinetics at glassy carbon electrodes by specific surface modification. Anal Chem 68: 3958-3965.

CHEN T, BARTON SC, BINYAMIN G, GAO ZQ, ZHANG YC, KIM HH AND HELLER A. 2001. A miniature biofuel cell. J Am Chem Soc 123: 8630-8631.

CHIDSEY CED. 1991. Free-energy and temperaturedependence of electron-transfer at the metal-electrolyte interface. Science 251: 919-922.

CINQUIN P ET AL. 2010. A glucose biofuel cell implanted in rats. PLoS One 5: e10476.

COONEY MJ, SVOBODA V, LAU C, MARTIN G AND MINTEER SD. 2008. Enzyme catalysed biofuel cells. Energy Environ Sci 1: 320-337.

COSNIER S. 2015. Electrochemical biosensors. Danvers: Pan Stanford. 412 p.

COSNIER S, MOUSTY C, GONDRAN CAND LEPELLECA. 2006. Entrapment of enzyme within organic and inorganic materials for biosensor applications: Comparative study. Mater Sci Eng C 26: 442-447.

COURJEAN O, GAO F AND MANO N. 2009. Deglycosylation of glucose oxidase for direct and efficient glucose electrooxidation on a glassy carbon electrode. Angew Chem Int Ed 48: 5897-5899.

CRESPILHO FN. 2013. Nanobioelectrochemistry: from implantable biosensors to green power generation. New York: Springer, $137 \mathrm{p}$. 
CRESPILHO FN, ESTEVES MC, SUMODJO PTA, PODLAHA EJ AND ZUCOLOTTO V. 2009a. Development of highly selective enzymatic devices based on deposition of permselective membranes on aligned nanowires. J Phys Chem C 113: 6037-6041.

CRESPILHO FN, GHICA ME, FLORESCU M, NART FC, OLIVEIRA ON AND BRETT CMA. 2006a. A strategy for enzyme immobilization on layer-by-layer dendrimergold nanoparticle electrocatalytic membrane incorporating redox mediator. Electrochem Commun 8: 1665-1670.

CRESPILHO FN, GHICA ME, GOUVEIA-CARIDADE C, OLIVEIRA ON AND BRETT CMA. 2008. Enzyme immobilisation on electroactive nanostructured membranes (ENM): Optimised architectures for biosensing. Talanta 76: 922-928.

CRESPILHO FN, IOST RM, TRAVAIN SA, OLIVEIRA ON AND ZUCOLOTTO V. 2009b. Enzyme immobilization on Ag nanoparticles/polyaniline nanocomposites. Biosens Bioelectron 24: 3073-3077.

CRESPILHO FN, ZUCOLOTTO V, BRETT CMA, OLIVEIRA ON AND NART FC. 2006b. Enhanced charge transport and incorporation of redox mediators in layerby-layer films containing PAMAM-encapsulated gold nanoparticles. J Phys Chem B 110: 17478-17483.

CRESPILHO FN, ZUCOLOTTO V, OLIVEIRA ON AND NART FC. 2006c. Electrochemistry of layer-by-layer films: a review. Int J Electrochem Sci 1: 194-214.

CZABAN JD. 1985. Electrochemical sensors in clinical chemistry: yesterday, today, tomorrow. Anal Chem 57: A345-356A.

DAI ZH, LIU SQ, JU HX AND CHEN HY. 2004. Direct electron transfer and enzymatic activity of hemoglobin in a hexagonal mesoporous silica matrix. Biosens Bioelectron 19: 861-867.

DATTA S, CHRISTENA LR AND RAJARAM YRS. 2013. Enzyme immobilization: an overview on techniques and support materials. 3 Biotech 3: 1-9.

DAVIS F AND HIGSON SPJ. 2007. Biofuel cells - Recent advances and applications. Biosens Bioelectron 22: 12241235.

DAVIS JJ, COLES RJ AND HILL HAO. 1997. Protein electrochemistry at carbon nanotube electrodes. J Electroanal Chem 440: 279-282.

DE SOUZA JCP, IOST RM AND CRESPILHO FN. 2016. Nitrated carbon nanoblisters for high-performance glucose dehydrogenase bioanodes. Biosens Bioelectron 77: 860865.

DE SOUZA JCP, SILVA WO, LIMA FHB AND CRESPILHO FN. IN PRESS. Enzyme activity evaluation by differential electrochemical mass spectrometry. Chem Commun.

DEGANI Y AND HELLER A. 1989. Electrical communication between redox centers of glucose oxidase and electrodes via electrostatically and covalently bound redox polymers. J Am Chem Soc 111: 2357-2358.

DRYHURST G. 2012. Biological electrochemistry. Academic Press, 548 p.

DWEK RA, EDGE CJ AND HARVEY DJ, WORMALD MR AND PAREKH RB. 1993. Analysis of glycoproteinassociated oligosaccharides. Annu Rev Biochem 62: 65100.

EDDOWES MJ AND HILL H. 1977. Novel method for investigation of electrochemistry of metalloproteins Cytochrome-C. J Chem Soc Chem: Commun 771-772.

EDGE ASB, FALTYNEK CR, HOF L, REICHERT JUNIOR LE AND WEBER P. 1981. Deglycosylation of glycoproteins by trifluormethanesulfonic acid. Anal Biochem 118: 131-137.

FALK M, BLUM Z AND SHLEEV S. 2012. Direct electron transfer based enzymatic fuel cells. Electrochim. Acta 82: 191-202.

FALK M, VILLARRUBIA CWN, BABANOVA S, ATANASSOV P AND SHLEEV S. 2013. Biofuel cells for biomedical applications: colonizing the animal kingdom. ChemPhysChem 14: 2045-2058.

FERRI S, KOJIMA K AND SODE K. 2011. Review of glucose oxidases and glucose dehydrogenases: a bird's eye view of glucose sensing enzymes. J Diabetes Sci Technol 5: 10681076.

FORROW NJ, SANGHERA GS AND WALTERS SJ. 2002. The influence of structure in the reaction of electrochemically generated ferrocenium derivatives with reduced glucose oxidase. J Chem Soc Dalton Trans 16: 3187-3194.

FOULDS NC. AND LOWE CR. 1986. Enzyme entrapment in electrically conducting polymers - Immobilization of glucose oxidase in polypyrrole and its application in amperometric glucose sensors. J Soc Chem Faraday Trans 1(82): 1259-1264.

FOULDS NC AND LOWE CR. 1988. Immobilization of glucose oxidase in ferrocene-modified pyrrole polymers. Anal Chem 60: 2473-2478.

FREW JE AND HILL HAO. 1988. Direct and indirect electron-transfer between electrodes and redox proteins. Eur J Biochem 172: 261-269.

GAN X, LIU T, ZHU XL AND LI GX. 2004. An electrochemical biosensor for nitric oxide based on silver nanoparticles and hemoglobin. Anal Sci 20: 1271-1275.

GAO H AND DUAN H. 2015. 2D and 3D graphene materials: preparation and bioelectrochemical applications. Biosens Bioelectron 65: 404-419.

GHINDILIS AL, ATANASOV P AND WILKINS E. 1997. Enzyme-catalyzed direct electron transfer: Fundamentals and analytical applications. Electroanalysis 9: 661-674.

GOODING JJ, WIBOWO R, LIU JQ, YANG WR, LOSIC D, ORBONS S, MEARNS FJ, SHAPTER JG AND HIBBERT 
DB. 2003. Protein electrochemistry using aligned carbon nanotube arrays. J Am Chem Soc 125: 9006-9007.

GORTON L AND DOMINGUEZ E. 2002. Electrocatalytic oxidation of NAD(P)H at mediator-modified electrodes. Rev Mol Biotechnol 82: 371-392.

GORTON L, LINDGREN A, LARSSON T, MUNTEANU FD, RUZGAS T AND GAZARYAN I. 1999. Direct electron transfer between heme-containing enzymes and electrodes as basis for third generation biosensors. Anal Chim Acta 400: 91-108.

GRABARCZYK DB, ASH PA AND VINCENT KA. 2014. Infrared spectroscopy provides insight into the role of dioxygen in the nitrosylation pathway of a [2Fe2S] cluster iron-sulfur protein. J Am Chem Soc 136: 11236-11239.

GRUBB WT. 1963. Catalysis, electrocatalysis, and hydrocarbon fuel cells. Nature 198: 883-884.

GUIDELLI R. 2016. Bioelectrochemistry of biomembranes and biomimetic membranes. New Jersey: Wiley, $352 \mathrm{p}$.

GUIDELLIR,ALOISIG, BECUCCIL, DOLFIA, MONCELLI MR AND BUONINSEGNI FT. 2001. New directions and challenges in electrochemistry - Bioelectrochemistry at metal/water interfaces. J Electroanal Chem 504: 1-28.

GUILBAULT GG. 1984. Analytical uses of immobilized enzymes. In: Pye EK and Wingard Jr. LB (Eds), Enzyme Engineering. New York: Springer US, p. 377-383.

GUISEPPI-ELIE A, LEI CH AND BAUGHMAN RH. 2002. Direct electron transfer of glucose oxidase on carbon nanotubes. Nanotechnology 13: 559-564.

GUISÁN JM. 2006. Immobilization of enzymes and cells. New Jersey: Humana Press, 449 p.

GULABOSKI R, MIRCESKI V, BOGESKI I AND HOTH M. 2012. Protein film voltammetry: electrochemical enzymatic spectroscopy. A review on recent progress. J Solid State Electrochem 16: 2315-2328.

GUO LH AND HILL HAP. 1991. Direct electrochemistry of proteins and enzymes. Adv Inorg Chem 36: 341-375.

HABEEB AFS AND HIRAMORO R. 1968. Reaction of proteins with glutaraldehyde. Arch Biochem Biophys 126: 16-26.

HALAMKOVA L, HALAMEK J, BOCHAROVA V, SZCZUPAK A, ALFONTA L AND KATZ E. 2012. Implanted biofuel cell operating in a living snail. J Am Chem Soc 134: 5040-5043.

HAMMER B AND NORSKOV JK. 1995. Electronic factors determining the reactivity of metal surfaces. Surf Sci 343: 211-220.

HAMMER B, NORSKOV JK, GATES BC AND KNOZINGER H. 2000. Theoretical surface science and catalysis - Calculations and concepts. Adv Catal 45: 71129.

HAMMERICH O AND ULSTRUP J. 2007. Bioinorganic electrochemistry. Springer, $310 \mathrm{p}$.
HAYAT MA. 1989. Colloid gold: principles, methods, and applications. San Diego: Academic Press, 536 p.

HEALY AJ, ASH PA, LENZ O AND VINCENT KA. 2013. Attenuated total reflectance infrared spectroelectrochemistry at a carbon particle electrode; unmediated redox control of a [NiFe]-hydrogenase solution. Phys Chem Chem Phys 15: 7055-7059.

HEALY AJ, REEVE HA AND VINCENT KA. 2011. Development of an infrared spectroscopic approach for studying metalloenzyme active site chemistry under direct electrochemical control. Faraday Discuss 148: 345-357.

HELLER A. 1992. Electrical connection of enzyme redox centers to electrodes. J Phys Chem 96: 3579-3587.

HELLER A AND DEGANI Y. 1998. Redox chemistry and interfacial behavior of biological molecules. New York: Plenum Press, 672 p.

HEXTER SV, ESTERLE TF AND ARMSTRONG FA. 2014. A unified model for surface electrocatalysis based on observations with enzymes. Phys Chem Chem Phys 16: 11822-11833.

HIDALGO R, ASH PA, HEALY AJ AND VINCENT KA. 2015. Infrared spectroscopy during electrocatalytic turnover reveals the $\mathrm{Ni}-\mathrm{L}$ active site state during $\mathrm{H}_{2}$ oxidation by a NiFe hydrogenase. Angew Chem Int Ed 54: 7110-7113.

HILLIARD LR, ZHAO XJ AND TAN WH. 2002. Immobilization of oligonucleotides onto silica nanoparticles for DNA hybridization studies. Anal Chim Acta 470: 51-56.

HUSH NS. 1958. Adiabatic rate processes at electrodes. 1. Energy-charge relationships. J Phys Chem 28: 962-972.

IOST RM AND CRESPILHO FN. 2012. Layer-by-layer selfassembly and electrochemistry: applications in biosensing and bioelectronics. Biosens Bioelectron 31: 1-10.

IOST RM, DA SILVA WC, MADURRO JM, MADURRO AGB, FERREIRA LF AND CRESPILHO FN. 2011a. Electrochemical nano(bio)sensors: advances, diagnosis and monitoring of diseases. Front Biosci E3 663-689.

IOST RM, MADURRO JM, MADURRO AGB, NANTES IL, CASELI L AND CRESPILHO FN. 2011b. Strategies of nano-manipulation for application in electrochemical biosensors. Int J Electrochem Sci 6: 2965-2997.

IOST RM, SALES FCPF, MARTINS MVA, ALMEIDA MC AND CRESPILHO FN. 2015. Glucose biochip based on flexible carbon fiber electrodes: in vivo diabetes evaluation in rats. ChemElectroChem 2: 518-521.

IVNITSKI D, BRANCH B, ATANASSOV P AND APBLETT C. 2006. Glucose oxidase anode for biofuel cell based on direct electron transfer. Electrochem Commun 8: 12041210.

JESIONOWSKI T, ZDARTA J AND KRAJEWSKA B. 2014. Enzyme immobilization by adsorption: a review. Adsorption 20: 801-821. 
JEUKEN L. 2016. Biophotoelectrochemistry: from bioelectrochemistry to biophotovoltaics. Switzerland: Springer International, $190 \mathrm{p}$.

JEUKEN LJC, JONES AK, CHAPMAN SK, CECCHINI G AND ARMSTRONG FA. 2002. Electron-transfer mechanisms through biological redox chains in multicenter enzymes. J Am Chem Soc 124: 5702-5713.

JONSSON G, GORTON L AND PETTERSSON L. 1989. Mediated electron transfer from glucose oxidase at a ferrocene-modified graphite electrode. Electroanalysis 1: 49-55.

KANG XH, WANG J, WU H, AKSAY IA, LIU J AND LIN YH. 2009. Glucose Oxidase-graphene-chitosan modified electrode for direct electrochemistry and glucose sensing. Biosens Bioelectron 25: 901-905.

KATCHALSKIKATZIR E. 1993. Immobilized enzymes - learning from past successes and failures. Trends Biotechnol. 11: 471-478.

KATZ E. 2014. Implantable bioelectronics: devices, materials and applications. New Jersey: Wiley VCH, 472 p.

KATZ E, BUCKMANN AF. AND WILLNER I. 2001. Selfpowered enzyme-based biosensors. J Am Chem Soc 123: 10752-10753.

KATZ E, LOTZBEYER T, SCHLERETH DD, SCHUHMANN W AND SCHMIDT HL. 1994. Electrocatalytic oxidation of reduced nicotinamide coenzymes at gold and platinum electrode surfaces modified with a monolayer of pyrroloquinoline quinone - effect of $\mathrm{Ca}^{2+}$ cations. J Electroanal Chem 373: 189-200.

KATZ E, SHIPWAY AN AND WILLNER I. 2007. Mediated electron-transfer between redox-enzymes and electrode supports. In Encyclopedia of Electrochemistry. Wiley$\mathrm{VCH}$.

KATZ E AND WILLNER I. 2004. Integrated nanoparticlebiomolecule hybrid systems: synthesis, properties, and applications. Angew Chem Int Ed 43: 6042-6108.

KAUFFMANN JM AND GUILBAULT GG. 1992. Enzyme electrode biosensors: theory and applications. In Bioanalytical application of enzymes, Methods of Biochemical Analysis, New York: Willey, p. 66-113.

KAVANAGH P AND LEECH D. 2013. Mediated electron transfer in glucose oxidising enzyme electrodes for application to biofuel cells: recent progress and perspectives. Phys Chem Chem Phys 15: 4859-4869.

KLIBANOV AM. 1979. Enzyme stabilization by immobilization. Anal Biochem 93: 1-25.

KLOTZBACH TL, WATT M, ANSARI Y AND MINTEER SD. 2008. Improving the microenvironment for enzyme immobilization at electrodes by hydrophobically modifying chitosan and Nafion polymers. J Membr Sci 311: 81-88.

KRZEMINSKI L, NDAMBA L, CANTERS GW, AARTSMA TJ, EVANS SD AND JEUKEN LJC. 2011.
Spectroelectrochemical investigation of intramolecular and interfacial electron-transfer rates reveals differences between nitrite reductase at rest and during turnover. J Am Chem Soc 133: 15085-15093.

KUILA T, BOSE S, KHANRA P, MISHRA AK, KIM NH AND LEE JH. 2011. Recent advances in graphene-based biosensors. Biosens Bioelectron 26: 4637-4648.

LAVIRON E. 1979. General expression of the linear potential sweep voltammogram in the case of diffusionless electrochemical systems. J Electroanal Chem 101: 19-28.

LE GOFF A, HOLZINGER M AND COSNIER S. 2011. Enzymatic biosensors based on SWCNT-conducting polymer electrodes. Analyst 136: 1279-1287.

LEBEDEVA NP, KOPER MTM, FELIU JM AND VAN SANTEN RA. 2002. Role of crystalline defects in electrocatalysis: Mechanism and kinetics of $\mathrm{CO}$ adlayer oxidation on stepped platinum electrodes. J Phys Chem B 106: 12938-12947.

LEE CA AND TSAI YC. 2009. Preparation of multiwalled carbon nanotube-chitosan-alcohol dehydrogenase nanobiocomposite for amperometric detection of ethanol. Sens Actuators B 138: 518-523.

LI D, MULLER MB, GILJE S, KANER RB AND WALLACE GG. 2008a. Processable aqueous dispersions of graphene nanosheets. Nat Nanotechnol 3: 101-105.

LI XL, ZHANG GY, BAI XD, SUN XM, WANG XR, WANG E AND DAI HJ. 2008b. Highly conducting graphene sheets and Langmuir-Blodgett films. Nat Nanotechnol 3: 538-542.

LIU AH, WEI MD, HONMA I AND ZHOU HS. 2005. Direct electrochemistry of myoglobin in titanate nanotubes film. Anal Chem 77: 8068-8074.

LUZ RAS AND CRESPILHO FN. 2016. Gold nanoparticlemediated electron transfer of cytochrome $\mathrm{c}$ on a selfassembled surface. RSC Adv 6: 62585-62593.

LUZ, RAS, IOST RM AND CRESPILHO FN. 2013. Nanomaterials for biosensors and implantable biodevices. New York: Springer.

LUZ RAS, PEREIRA AR, DE SOUZA JCP, SALES FCPF AND CRESPILHO FN. 2014. Enzyme biofuel cells: thermodynamics, kinetics and challenges in applicability. ChemElectroChem 1: 1751-1777.

LY HK, SEZER M, WISITRUANGSAKUL N, FENG JJ, KRANICH A, MILLO D, WEIDINGER IM, ZEBGER I, MURGIDA DH AND HILDEBRANDT P. 2011. Surfaceenhanced vibrational spectroscopy for probing transient interactions of proteins with biomimetic interfaces: electric field effects on structure, dynamics and function of cytochrome c. FEBS J 278: 1382-1390.

MACVITTIE K, CONLON T AND KATZ E. 2015. A wireless transmission system powered by an enzyme biofuel cell implanted in an orange. Bioelectrochemistry 106: 28-33. 
MACVITTIE K, HALAMEK J, HALAMKOVA L, SOUTHCOTT M, JEMISON WD, LOBELD R AND KATZ E. 2013. From "cyborg” lobsters to a pacemaker powered by implantable biofuel cells. Energy Environ Sci 6: 81-86.

MARCUS RA. 1956. On the theory of oxidation-reduction reactions involving electron transfer. J Chem Phys 24: 966-978.

MARRITT, SJ, VAN WONDEREN JH, CHEESMAN MR AND BUTT JN. 2006. Magnetic circular dichroism of hemoproteins with in situ control of electrochemical potential: "MOTTLE". Anal Biochem 359: 79-83.

MARTINS, MVA, PEREIRA AR, LUZ RAS, IOST RM AND CRESPILHO FN. 2014. Evidence of short-range electron transfer of a redox enzyme on graphene oxide electrodes. Phys Chem Chem Phys 16: 17426-17436.

MASA J AND SCHUHMANN W. 2016. Electrocatalysis and bioelectrocatalysis - Distinction without a difference. Nano Energy 29: 466-475.

MATEO C, PALOMO JM, FERNANDEZ-LORENTE G, GUISAN, JM AND FERNANDEZ-LAFUENTE R. 2007. Improvement of enzyme activity, stability and selectivity via immobilization techniques. Enzyme Microb Technol 40: 1451-1463.

MAY SW. 1999. Applications of oxidoreductases. Curr Opin Biotechnol 10: 370-375.

MAY SW AND PADGETTE SR. 1983. Oxidoreductase enzymes in biotechnology - current status and future potential. Bio-Technology 1: 677-686.

MCCALL KA, HUANG CC, AND FIERKE CA. 2000. Function and mechanism of zinc metalloenzymes. J Nutr 130: 1437S-1446S.

MCCORD JM AND FRIDOVICH I. 1970. The utility of superoxide dismutase in studying free radical reactions. $\mathrm{J}$ Biol Chem 245: 1374-1377.

MCCRORY CCL, UYEDA C AND PETERS JC. 2012. Electrocatalytic hydrogen evolution in acidic water with molecular cobalt tetraazamacrocycles. J Am Chem Soc 134: 3164-3170.

MIYAKE T, HANEDA K, NAGAI M, YATAGAWA Y, ONAMI H, YOSHINO S, ABE T AND NISHIZAWA M. 2011. Enzymatic biofuel cells designed for direct power generation from biofluids in living organisms. Energy Environ Sci 4: 5008-5012.

MOEHLENBROCK MJ AND MINTEER SD. 2008. Extended lifetime biofuel cells. Chem Soc Rev 37: 1188-1196.

MURRAY RW. 1984. Chemically modified electrodes. In: Bard JA (Ed), Electroanalytical Chemistry. New York: Marcel Dekker, p. 191-368.

MUSAMEH M, WANG J, MERKOCI A AND LIN YH. 2002. Low-potential stable NADH detection at carbon-nanotubemodified glassy carbon electrodes. Electrochem Commun 4: 743-746.
NELSON DL AND COX MM. 2005. Principles of Biochemistry. New York: Freeman and Company, $1340 \mathrm{p}$.

OLIVEIRA ON, IOST RM, SIQUEIRA JR, CRESPILHO FN AND CASELI L. 2014. Nanomaterials for diagnosis: challenges and applications in smart devices based on molecular recognition. ACS Appl Mater Interfaces 6: 14745-14766.

OLYVEIRA GM, IOST RM, LUZ RAS AND CRESPILHO FN. 2012a. Biofuel cells: bioelectrochemistry applied to the generation of green electricity. In: de Souza FL and Leite ER (Eds), Nanoenergy.Berlin: Springer, p. 101-123.

OLYVEIRA GM, KIM JH, MARTINS MVA, IOST RM, CHAUDHARI KN, YU JS AND CRESPILHO FN. 2012b. Flexible carbon cloth electrode modified by hollow coremesoporous shell carbon as a novel efficient bio-anode for biofuel cell. J Nanosci Nanotechnol 12: 356-360.

PAENGNAKORN P, ASH PA, SHAW S, DANYAL K, CHEN T, DEAN DR, SEEFELDT LC AND VINCENT KA. 2017. Infrared spectroscopy of the nitrogenase MoFe protein under electrochemical control: potential-triggered CO binding. Chem Sci 8: 1500-1505.

PAGE CC, MOSER CC, CHEN XX AND DUTTON PL. 1999. Natural engineering principles of electron tunnelling in biological oxidation-reduction. Nature 402: 47-52.

PANDEY PC. 1988. A new conducting polymer-coated glucose sensor. J Chem Soc Faraday Trans I 84: 2259-2265.

PATEL T, BRUCE J, MERRY A, BIGGE C, WORMALD M, JAQUES A AND PAREKH R. 1993. Use of hydrazine to release in intact and unreduced form both $\mathrm{N}$-linked and O-linked oligosaccharides from glycoproteins. Biochemistry 32: 679-693.

PATOLSKY F, TAO G, KATZ E AND WILLNER I. 1998. $\mathrm{C}_{60}$-mediated bioelectrocatalyzed oxidation of glucose oxidase. J Electroanal Chem 454: 9-13.

PEREIRA AR, DE SOUZA JCP, GONÇALVES AD, PAGNONCELLI KC AND CRESPILHO FN. 2017a. Bioelectrooxidation of ethanol using NAD-dependent alcohol dehydrogenase on oxidized flexible carbon fiber arrays. J Bras Chem Soc 28: 1698-1707.

PEREIRA AR, DE SOUZA JCP, IOST RM, SALES FCPF AND CRESPILHO FN. 2016. Application of carbon fibers to flexible enzyme electrodes. J Electroanal Chem 780: 396-406.

PEREIRA AR, IOST RM, MARTINS MVA, YOKOMIZO CH, DA SILVA WC, NANTES IL AND CRESPILHO FN. 2011. Molecular interactions and structure of a supramolecular arrangement of glucose oxidase and palladium nanoparticles. Phys Chem Chem Phys 13: 12155-12162.

PEREIRA AR, LUZ RAS, DALMATI FCDA AND CRESPILHO FN. 2017b. Protein oligomerization based on Brønsted acid reaction. ACS Catal 7: 3082-3088. 
PORATH J, CARLSSON J, OLSSON I AND BELFRAGE G. 1975. Metal chelate affinity chromatography, a new approach to protein fractionation. Nature 258: 598-599.

PREVOTEAU A, COURJEAN O AND MANO N. 2010. Deglycosylation of glucose oxidase to improve biosensors and biofuel cells. Electrochem Commun 12: 213-215.

RABAEY K, ANGENENT L AND SCHRODER U. 2009. Bioelectrochemical systems: from extracellular electron transfer to biotechnological application. London: IWA Publishing, $524 \mathrm{p}$.

RASMUSSEN M, RITZMANN RE, LEE I, POLLACK AJ AND SCHERSON D. 2012. An implantable biofuel cell for a live insect. J Am Chem Soc 134: 1458-1460.

REDDAIAH K AND REDDY TM. 2014. Electrochemical biosensor based on silica sol-gel entrapment of horseradish peroxidase onto the carbon paste electrode toward the determination of 2-aminophenol in non-aqueous solvents: A voltammetric study. J Mol Liq 196: 77-85.

REEVES JH, SONG S AND BOWDEN EF. 1993. Application of square-wave voltammetry to strongly adsorbed quasireversible redox molecules. Anal Chem 65: 683-688.

REUILLARD B, LE GOFF A, AGNES C, HOLZINGER M, ZEBDA A, GONDRAN C, ELOUARZAKI K AND COSNIER S. 2013. High power enzymatic biofuel cell based on naphthoquinone-mediated oxidation of glucose by glucose oxidase in a carbon nanotube 3D matrix. Phys Chem Chem Phys 15: 4892-4896.

RUSLING JF, WANG B AND YUN S. 2008. Electrochemistry of redox enzymes. In: Bartlett P (Ed), Bioelectrochemistry: fundamentals, experimental techniques and applications. J Wiley \& Sons, p. 39-85.

RUSLING JF AND ZHANG Z. 2001. Thin films on electrodes for direct protein electron transfer. In: Nalwa RW (Ed), Handbook of surfaces and interfaces of materials. San Diego: Academic Press, p. 33-71.

RUSLING JF. 2003. Designing functional biomolecular films on electrodes. In: Rusling JF (Ed), Biomolecular films. New York: Marcel Dekker, p. 1-64.

SALES FCPF, IOST RM, MARTINS MVA, ALMEIDA MC AND CRESPILHO FN. 2013. An intravenous implantable glucose/dioxygen biofuel cell with modified flexible carbon fiber electrodes. Lab Chip 13: 468-474.

SALVERDA JM, PATIL AV, MIZZON G, KUZNETSOVA S, ZAUNER G, AKKILIC N, CANTERS GW, DAVIS JJ, HEERING HA AND AARTSMA TJ. 2010. Fluorescent cyclic voltammetry of immobilized azurin: direct observation of thermodynamic and kinetic heterogeneity. Angew Chem Int Ed 49: 5776-5779.

SASSOLAS A, BLUM LJ AND LECA-BOUVIER BD. 2012. Immobilization strategies to develop enzymatic biosensors. Biotechnol Adv 30: 489-511.

SEZER M, FRIELINGSDORF S, MILLO D, HEIDARY $\mathrm{N}$, UTESCH T, MROGINSKI MA, FRIEDRICH B,
HILDEBRANDT P, ZEBGER I AND WEIDINGER IM. 2011. Role of the HoxZ Subunit in the Electron Transfer Pathway of the Membrane-Bound [NiFe]-Hydrogenase from Ralstonia eutropha Immobilized on Electrodes. J Phys Chem B 115: 10368-10374.

SHAKED Z AND WHITESIDES GM. 1980. Enzymecatalyzed organic synthesis: NADH regeneration by using formate dehydrogenase. J Am Chem Soc 102: 7104-7105.

SHAN CS, YANG HF, SONG JF, HAN DX, IVASKA A AND NIU L. 2009. Direct electrochemistry of glucose oxidase and biosensing for glucose based on graphene. Anal Chem 81: 2378-2382.

SHELDON RA. 2007. Enzyme immobilization: The quest for optimum performance. Adv Synth Catal 349: 1289-1307.

SHLEEV S, JAROSZ-WILKOLAZKA A, KHALUNINA A, MOROZOVA O, YAROPOLOV A, RUZGAS T AND GORTON L. 2005a. Direct electron transfer reactions of laccases from different origins on carbon electrodes. Bioelectrochemistry 67: 115-124.

SHLEEV S, TKAC J, CHRISTENSON A, RUZGAS T, YAROPOLOV AI, WHITTAKER JW AND GORTON L. 2005b. Direct electron transfer between copper-containing proteins and electrodes. Biosens Bioelectron 20: $2517-$ 2554.

SILVEIRA CM, QUINTAS PO, MOURA I, MOURA JJG, HILDEBRANDT P, ALMEIDA MG AND TODOROVIC S. 2015. SERR spectroelectrochemical study of cytochrome $c d_{1}$ nitrite reductase co-immobilized with physiological redox partner cytochrome $c_{552}$ on biocompatible metal electrodes. PLoS ONE 10: e0129940.

SIQUEIRA JR, CASELI L, CRESPILHO FN, ZUCOLOTTO $\mathrm{V}$ AND OLIVEIRA ON. 2010. Immobilization of biomolecules on nanostructured films for biosensing. Biosens Bioelectron 25: 1254-1263.

SUCHETA A, CAMMACK R, WEINER J AND ARMSTRONG FA. 1993. Reversible voltammetry of fumarate reductase immobilized on an electrode surface. Biochemistry 32: 5455-5465.

SZCZUPAK A, HALAMEK J, HALAMKOVA L, BOCHAROVA V, ALFONTA L AND KATZ E. 2012. Living battery - biofuel cells operating in vivo in clams. Energy Environ Sci 5: 8891-8895.

TARASEVICH MR. 1985. Bioelectrocatalysis. In: Srinivasan SC, Yu A, Chizmadzhev YA, Bockris JOM, Conway $\mathrm{BE}$ and Yeager E (Eds), Comprehensive treatise of electrochemistry. New York: Plenum Press, 788 p.

TARASEVICH MR, YAROPOLOV AI, BOGDANOVSKAYA VA AND VARFOLOMEEV SD. 1979. Electrocatalysis of a cathodic oxygen reduction by laccase. Bioelectrochem Bioenerg 6: 393-403.

TERSOFF J AND FALICOV LM. 1981. Electronic structure and local atomic configurations of flat and stepped (111) surfaces of Ni and Cu. Phys Chem B 24: 754-764. 
TURNER APF. 2013. Biosensors: sense and sensibility. Chem Soc Rev 42: 3184-3196.

WALSH C. 1980. Flavin coenzymes: at the crossroads of biological redox chemistry. Acc Chem Res 13: 148-155.

WALZ D, TEISSIÉ J AND MILAZZO G. 2004. Bioelectrochemistry of membranes. New York: Springer, $240 \mathrm{p}$.

WANG G, XU JJ AND CHEN HY. 2002a. Interfacing cytochrome $\mathrm{c}$ to electrodes with a DNA - carbon nanotube composite film. Electrochem Commun 4: 506-509.

WANG J. 2008. Electrochemical glucose biosensors. Chem Rev 108: 814-825.

WANG JX, LI MX, SHI ZJ, LI NQ AND GU ZN. 2002 b. Direct electrochemistry of cytochrome $\mathrm{c}$ at a glassy carbon electrode modified with single-wall carbon nanotubes. Anal Chem 74: 1993-1997.

WANG W, NEMA S AND TEAGARDEN D. 2010. Protein aggregation - pathways and influencing factors. Int $\mathrm{J}$ Pharm 390: 89-99.

WILLNER B, KATZ E AND WILLNER I. 2006. Electrical contacting of redox proteins by nanotechnological means. Curr Opin Biotechnol 17: 589-596.

WILLNER I. 2002. Biomaterials for sensors, fuel cells, and circuitry. Science 298: 2407-2408.

WILLNER I, WILLNER B AND KATZ E. 2007. Biomoleculenanoparticle hybrid systems for bioelectronic applications. Bioelectrochemistry 70: 2-11.

WILSON R AND TURNER APF. 1992. Glucose oxidase: an ideal enzyme. Biosen Bioelectron 7: 165-185.

WU SP, BELLEI M, MANSY SS, BATTISTUZZI G, SOLA M AND COWAN JA. 2011. Redox chemistry of the Schizosaccharomyces pombe ferredoxin electron-transfer domain and influence of Cys to Ser substitutions. J Inorg Chem 105: 806-811.

XIAO Y, PATOLSKY F, KATZ E, HAINFELD JF AND WILLNER I. 2003. "Plugging into enzymes": Nanowiring of redox enzymes by a gold nanoparticle. Science 299: $1877-1881$.

YAHIRO AT, LEE SM AND KIMBLE DO. 1964. Bioelectrochemistry. I. Enzyme utilizing biofuel cell studies. Biochim Biophys Acta 88: 375-383.
YAROPOLOV AI, MALOVIK V, VARFOLOMEEV SD AND BEREZIN IV. 1979. Electroreduction of hydrogen peroxide on an electrode with immobilized peroxidase. Dokl Akad Nauk 249: 1399-1401.

YEH P AND KUWANA T. 1977. Reversible electrode-reaction of cytochrome-C. Chem Lett 1145-1148.

ZEBDAA ET AL. 2013. Single glucose biofuel cells implanted in rats power electronic devices. Sci Rep 3: 1516.

ZHANG Y, HE PL AND HU NF. 2004. Horseradish peroxidase immobilized in $\mathrm{TiO}_{2}$ nanoparticle films on pyrolytic graphite electrodes: direct electrochemistry and bioelectrocatalysis. Electrochim Acta 49: 1981-1988.

ZHANG YB, TAN YW, STORMER HL AND KIM P. 2005. Experimental observation of the quantum Hall effect and Berry's phase in graphene. Nature 438: 201-204.

ZHAO HY, ZHENG W, MENG ZX, ZHOU HM, XU XX, LI Z AND ZHENG YF. 2009. Bioelectrochemistry of hemoglobin immobilized on a sodium alginate-multiwall carbon nanotubes composite film. Biosens Bioelectron 24: 2352-2357.

ZHAO JG, HENKENS RW, STONEHUERNER J, ODALY JP AND CRUMBLISS AL. 1992. Direct electron-transfer at horseradish peroxidase - colloidal gold modified electrodes. J Electroanal Chem 327: 109-119.

ZHAO S, ZHANG K, BAI Y, YANG W AND SUN C. 2006. Glucose oxidase/colloidal gold nanoparticles immobilized in Nafion film on glassy carbon electrode: direct electron transfer and electrocatalysis. Bioelectrochemistry 69: 158163.

ZHAO YD, ZHANG WD, CHEN H AND LUO QM. 2002. Direct electron transfer of glucose oxidase molecules adsorbed onto carbon nanotube powder microelectrode. Anal Sci 18: 939-941.

ZOUNGRANA T, FINDENEGG GH AND NORDE W. 1997. Structure, stability, and activity of adsorbed enzymes. J Colloid Interface Sci 190: 437-448.

ZWOLINSKI BJ, MARCUS RJ AND EYRING H. 1955. Inorganic oxidation-reduction reactions in solution electron transfers. Chem Rev 55: 157-180. 